\section{Opiates increase the number of hypocretin-producing cells in human and mouse brain and reverse cataplexy in a mouse model of narcolepsy}

\author{
Thomas C. Thannickal ${ }^{1,2}$, Joshi John ${ }^{1,2}$, Ling Shan ${ }^{1,2}$, Dick F. Swaab ${ }^{3}$, Ming-Fung Wu ${ }^{1,2}$, \\ Lalini Ramanathan $^{1,2}$, Ronald McGregor ${ }^{1,2}$, Keng-Tee Chew ${ }^{1,2}$, Marcia Cornford ${ }^{4}$, \\ Akihiro Yamanaka ${ }^{5}$, Ayumu Inutsuka ${ }^{5}$, Rolf Fronczek ${ }^{6,7}$, Gert Jan Lammers ${ }^{6,7}$, \\ Paul F. Worley ${ }^{8}$, Jerome M. Siegel ${ }^{1,2 *}$
}

The changes in brain function that perpetuate opiate addiction are unclear. In our studies of human narcolepsy, a disease caused by loss of immunohistochemically detected hypocretin (orexin) neurons, we encountered a control brain (from an apparently neurologically normal individual) with $50 \%$ more hypocretin neurons than other control human brains that we had studied. We discovered that this individual was a heroin addict. Studying five postmortem brains from heroin addicts, we report that the brain tissue had, on average, $54 \%$ more immunohistochemically detected neurons producing hypocretin than did control brains from neurologically normal subjects. Similar increases in hypocretin-producing cells could be induced in wild-type mice by long-term (but not short-term) administration of morphine. The increased number of detected hypocretin neurons was not due to neurogenesis and outlasted morphine administration by several weeks. The number of neurons containing melanin-concentrating hormone, which are in the same hypothalamic region as hypocretin-producing cells, did not change in response to morphine administration. Morphine administration restored the population of detected hypocretin cells to normal numbers in transgenic mice in which these neurons had been partially depleted. Morphine administration also decreased cataplexy in mice made narcoleptic by the depletion of hypocretin neurons. These findings suggest that opiate agonists may have a role in the treatment of narcolepsy, a disorder caused by hypocretin neuron loss, and that increased numbers of hypocretin-producing cells may play a role in maintaining opiate addiction.

\section{INTRODUCTION}

The annual rate of opiate overdose deaths in the United States has increased fourfold in the last 17 years, with more than 300,000 deaths since 2000 . Addicts are unable to overcome opiate addiction, even as they realize the destructive effect it is having on them and their families (1). Prior work suggests that hypocretin cell activity is linked to pleasure-mediated arousal and, hence, may play a role in perpetuating addiction (2-4).

Previously, we reported that human narcolepsy is linked to, on average, a $90 \%$ loss of immunohistochemically identified hypocretinproducing cells (5). More recently, we reported a decreased number of immunohistochemically identified hypocretin neurons in Parkinson's disease $(6,7)$. In analyzing postmortem brain tissue from neurologically normal control individuals, we unexpectedly encountered a brain with $50 \%$ more hypocretin-producing neurons than we had found in any of the other control human brain tissues we had studied.

\footnotetext{
${ }^{1}$ Neuropsychiatric Institute and Brain Research Institute, University of California Los Angeles, Los Angeles, CA 90095, USA. ${ }^{2}$ Neurobiology Research, Veterans Administration Greater Los Angeles Healthcare System, 16111 Plummer Street, North Hills, CA 91343, USA. ${ }^{3}$ Netherlands Institute for Neuroscience, an Institute of the Royal Netherlands Academy of Arts and Sciences, Amsterdam, Netherlands. ${ }^{4}$ Department of Pathology, Harbor University of California, Los Angeles, Medical Center, Torrance, CA 90509, USA. ${ }^{5}$ Department of Neuroscience II, Research Institute of Environmental Medicine, Nagoya University, Furo-cho, Chikusa-ku, Nagoya 464-8601, Japan. ' Leiden University Medical Centre, Department of Neurology, Leiden, Netherlands. ${ }^{7}$ Sleep Wake Centre, Stichting Epilepsie Instellingen Nederland, Heemstede, Netherlands. ${ }^{8}$ The Solomon H. Snyder Department of Neuroscience, Johns Hopkins University School of Medicine, Baltimore, MD 21205, USA.

*Corresponding author. Email: jsiegel@ucla.edu
}

Further investigation revealed that this individual was a former heroin addict.

Here, we acquired postmortem brain tissue from four additional human heroin addicts. We saw a greatly elevated number of hypocretinproducing cells in the brain of each addict. We then explored whether administering morphine to wild-type mice would produce a similar increase in hypocretin-producing cells, what the effects of the dose and schedule of administration effects were on the magnitude of the increase, and how long the changes in hypocretin neuron number and cell size persisted after the cessation of administration. We then exploited the finding of an increase in hypocretin cells induced by opiate administration in mice to see whether morphine might have beneficial effects in a mouse model of narcolepsy where hypocretin cell number had been reduced to mimic the low number of hypocretin cells found in human narcolepsy.

\section{RESULTS}

An increased number of immunohistochemically positive hypocretin (orexin) neurons in the brains of human heroin addicts

There was an average increase of $54 \%$ in the number of detectable hypocretin-producing neurons in the postmortem brain tissue from five human heroin addicts relative to matched control brains $[P=$ $0.0009, t=8.89, \mathrm{df}=10$ ( $t$ test); Table 1 and Fig. $1 \mathrm{~A}]$. The range of increase in the addicts was 36 to $74 \%$ above mean control values. Hypocretin-producing cells were found to be $22 \%$ smaller in the brains of addicts compared to controls $[P<0.01, t=2.78, \mathrm{df}=10$ ( $t$ test); Fig. 1, B and D]. About $90 \%$ of hypocretin-producing neurons 
Table 1. Characteristics of addicts, narcoleptic patients, and control subjects. PMI, postmortem interval; avg, average; MI, myocardial infarction; N/A, not available; SLE, systemic lupus erythematosus.

\begin{tabular}{|c|c|c|c|c|c|c|c|c|c|}
\hline Subject & Sex & Age & Cause of death & Medications & PMI & pH & $\begin{array}{l}\text { Years } \\
\text { in fix }\end{array}$ & $\begin{array}{c}\text { Estimated } \\
\text { hypocretin cell no. }\end{array}$ & \\
\hline A-1 & M & 38 & Heroin intoxication & $\begin{array}{c}\text { Oxycodone abuse, } \\
\text { smoked } 1 \frac{1}{2} \text { packs } \\
\text { per day }\end{array}$ & 20.0 & 6.84 & 3.5 & 121,173 & \\
\hline$A-2$ & $\mathrm{~F}$ & 26 & $\begin{array}{c}\text { Asthma } \\
\text { complicating Narc } \\
\text { intoxication }\end{array}$ & $\begin{array}{l}\text { Heroin, cocaine, } \\
\text { methadone }(110 \mathrm{~g}) \text { for } \\
8 \text { months, nonsmoker }\end{array}$ & 4.0 & 6.63 & 3.5 & 130,719 & \\
\hline$A-4$ & M & 28 & $\begin{array}{l}\text { Methadone } \\
\text { intoxication and } \\
\text { cocaine use }\end{array}$ & $\begin{array}{l}\text { Heroin, cocaine, } \\
\text { methadone }\end{array}$ & 13.0 & 5.52 & 3 & 123,810 & \\
\hline$C-1$ & $\mathrm{~F}$ & 42 & Breast cancer & & 15.0 & $\mathrm{~N} / \mathrm{A}$ & 1.0 & 84,546 & \\
\hline C-2 & M & 32 & MI, aneurism & & N/A & $N / A$ & 8.0 & 89,652 & \\
\hline$C-3$ & M & 61 & $\begin{array}{l}\text { Pneumonia, } \\
\text { testicular tumor }\end{array}$ & & N/A & $\mathrm{N} / \mathrm{A}$ & 8.0 & 65,833 & \\
\hline C-4 & $\mathrm{F}$ & 44 & Breast cancer & & N/A & $N / A$ & 8.0 & 86,354 & \\
\hline C-5 & $\mathrm{F}$ & 27 & $\begin{array}{l}\text { Mild hypoxia, } \\
\text { arterial calcification, } \\
\text { congenital heart } \\
\text { defect, coronary } \\
\text { artery } \\
\text { atherosclerosis }\end{array}$ & & N/A & $\mathrm{N} / \mathrm{A}$ & 1.5 & 78,656 & \\
\hline NBB-00-142 & $\mathrm{F}$ & 82 & $\mathrm{Ml}$ & & 5.3 & 6.6 & 0.1 & 70,976 & Avg: 88,582 \\
\hline \multicolumn{10}{|c|}{ Narcolepsy with cataplexy } \\
\hline \multirow[t]{3}{*}{ NBB-08023 } & $\mathrm{F}$ & 66 & Heart failure & $\begin{array}{c}\text { Amphetamine, } \\
5.45 \mathrm{mg}, 1 \text { time/day }\end{array}$ & & & & & \\
\hline & & & & $\begin{array}{c}\text { Modafinil, } 100 \mathrm{mg} \\
3 \text { times/day }\end{array}$ & 7.0 & 6.57 & 0.1 & 3276 & $3.6 \%$ control \\
\hline & & & & $\begin{array}{c}\text { Sodium oxybate at } \\
500 \mathrm{mg} / \mathrm{ml}, 2 \text { times } \\
6 \mathrm{ml} / \text { day }\end{array}$ & & & & & \\
\hline \multicolumn{10}{|c|}{ Narcolepsy with cataplexy morphine-treated hypersomnia } \\
\hline NBB-01064 & $\mathrm{F}$ & 85 & $\begin{array}{l}\text { Chronic pain } \\
\text { syndrome with } \\
\text { palliative sedation }\end{array}$ & $\begin{array}{c}\text { Morphine, } 10 \mathrm{mg} \\
2 \text { times/day (9 years) }\end{array}$ & 3.4 & 6.77 & 0.1 & 16,834 & $19 \%$ control \\
\hline
\end{tabular}


A

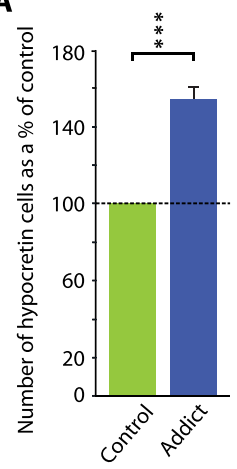

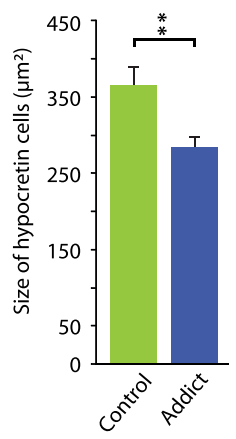

C

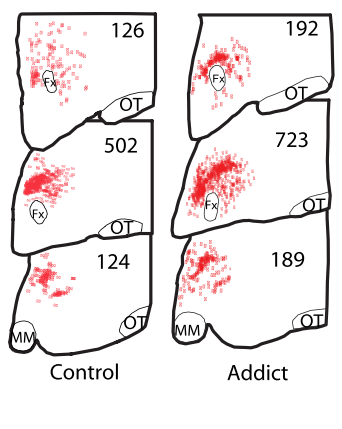

D

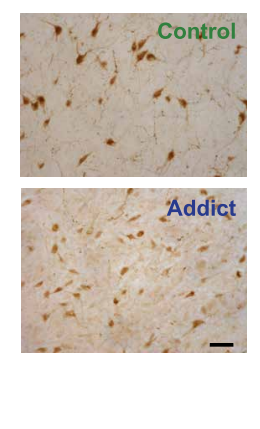

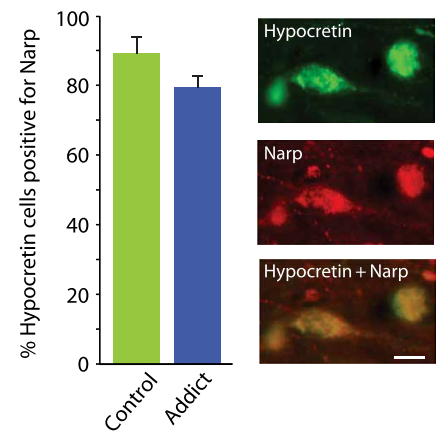

Fig. 1. Postmortem brain tissue from heroin addicts shows an increased number of hypocretin-producing neurons. Subject characteristics are presented in Table1. (A) Immunohistochemistry showed that there was a $54 \%$ increase in the number of detectable hypocretin neurons in hypothalamic brain tissue from human heroin addicts $(n=5)$ relative to hypothalamic tissue from human control subjects $[n=7 ; P=0.0009, t=8.89, \mathrm{df}=10(t$ test)]. (B) Immunohistochemical staining of postmortem brain tissue showed that hypocretin cells were $22 \%$ smaller in brain tissue from heroin addicts compared to control subjects $[P<0.01, t=2.78, \mathrm{df}=10(t$ test $)]$. (C) Neurolucida mapping illustrates the distribution and increased number of hypocretin cells in brain tissue from heroin addicts relative to control subjects. Representative counts are given at three anterior-posterior positions: OT, optic tract; MM, mammillary bodies; Fx, fornix. (D) A representative example of immunohistochemical labeling of hypocretin cells in brain tissue from control individuals and heroin addicts is shown. Scale bar, $50 \mu \mathrm{m}$. (E) Left: Immunohistochemical staining showing that about $90 \%$ of hypocretin neurons in human brain tissue from control individuals also contained the neuropeptide Narp. This percentage did not significantly differ in brain tissue from human heroin addicts. Right: Representative images of immunohistochemical double staining for hypocretin (Hcrt) and Narp in hypothalamus of brain tissue from a heroin addict. ${ }^{* * *} P<0.001,{ }^{* *} P<0.01, t$ test, compared to control.

in the brains of human control subjects also contained Narp (neuronal activity-regulated pentraxin), a secreted neuronal pentraxin that co-localizes with hypocretin in hypothalamic neurons (8). This percentage was similar in the larger number of hypocretin neurons observed in human heroin addicts (Fig. 1E).

\section{Dose-dependent effects of morphine administration on hypocretin-producing cells in the brains of wild-type mice}

To determine whether the differences in the number and size of hypocretin-producing neuron somas seen between human heroin addicts and controls might be induced by opiates, we administered morphine to mice at several doses for varying time periods. Subcutaneous injection of fixed and escalating doses of morphine for 7 days did not significantly change the number of hypocretin cells detected in the mouse brain. However, 14-day administration of either dose schedule increased hypocretin cell number relative to saline injection $[P=0.01, t=4.23, \mathrm{df}=4$ and $P=0.01, t=4.52$, $\mathrm{df}=4$ ( $t$ tests), respectively; Fig. 2A]. Fixed morphine doses of $10 \mathrm{mg} / \mathrm{kg}$ or greater for a single 2-week period increased hypocretin cell number $\left[F_{7,16}=8.1, P<0.001\right.$, analysis of variance (ANOVA) $]$ with a maximal average increase of $38 \%$ at the $50 \mathrm{mg} / \mathrm{kg}$ dose (Fig. 2B). With daily dosing for a 60-day period, the magnitude of changes in hypocretin cell number was smaller than that after 14 days of morphine administration $\left(F_{3,12}=13.5, P<0.001\right.$, ANOVA, normality, variance tests passed between groups; Fig. 2C). The effect on hypocretin cell number was largest in the lateral hypothalamus (LH), but an increase in hypocretin cell number was also seen in the medial hypothalamus (MH) [LH: $P=0.001, t=11.94, \mathrm{df}=7$; $\mathrm{MH}: P=0.05$, $t=2.44, \mathrm{df}=7$ ( $t$ tests); Fig. 2D]. After 14 days of administration of morphine $(50 \mathrm{mg} / \mathrm{kg})$, hypocretin cell number remained elevated for an additional 4 to 8 weeks $[P=0.001, t=6.13, \mathrm{df}=8$ ( $t$ test, ANOVA, normality, variance tests passed between groups), $F_{5,22}=$ 9.4, $P<0.001$; Fig. 2E]. After 60 days of administration of the same morphine dose (bottom), the elevation of hypocretin cell number persisted for an additional 2 weeks after the end of drug administration
$\left[F_{5,22}=6.3, P<0.001\right.$ (ANOVA, normality, variance tests passed between groups); Fig. $2 \mathrm{E}$ ]. Figure $2 \mathrm{~F}$ shows the time course of recovery from hypocretin cell shrinkage after daily administration of morphine $(50 \mathrm{mg} / \mathrm{kg})$ or saline to five experimental and five control mice for 2 weeks. Hypocretin cell size increased toward control values over the 4-week period after cessation of morphine administration $\left[F_{5,58}=5.3, P<0.0005\right.$ (ANOVA); Fig. $\left.2 \mathrm{~F}\right]$. The increased number of hypocretin-producing cells was within the regions containing hypocretin cells under baseline conditions $[P=0.001, t=$ $4.88, \mathrm{df}=10$; Fig. $2 \mathrm{G}]$. There was no change in the percentage of Narp-containing cells within the increased number of hypocretinproducing cells in mice treated with morphine $(50 \mathrm{mg} / \mathrm{kg})$ for 14 days (Fig. 2H).

Because subcutaneous implantation of morphine pellets is commonly used in opiate research, we studied the effect of implantation of morphine pellets $(25 \mathrm{mg}$ ) or control pellets in 14 mice. Figure 2I shows the effects of subcutaneously administered morphine pellets compared to control pellets on the distribution of hypocretin cell size 72 hours after implantation. On average, cell size was decreased by $23 \%$ in response to morphine pellet implantation $[U=5239, P<$ 0.01 (Mann-Whitney $U$ test); Fig. 2I]. Thus, as with morphine injection, morphine pellet implantation resulted in a reduction in hypocretin cell size, shifting the entire population distribution downward. However, the continuous presence of morphine for 7 or 14 days, produced by replacing pellets every 3 days, did not produce a significant increase in hypocretin cell number (Fig. 2J). The number of melanin-concentrating hormone $(\mathrm{MCH})$-producing cells in the brains of mice was not affected by injection of morphine at 50 or $100 \mathrm{mg} / \mathrm{kg}$ for 14 days (Fig. $2 \mathrm{~K}$ ). There was no change in $\mathrm{MCH}$ cell size after 14 days of morphine administration to the mice (Fig. 2L).

\section{Changes in preprohypocretin, Narp, preprodynorphin, and $\mathrm{MCH}$ in response to morphine}

An escalating dose of morphine (100 mg/kg; Fig. 3, A to C) was given to wild-type mice for 14 days. Quantitative polymerase chain 
A

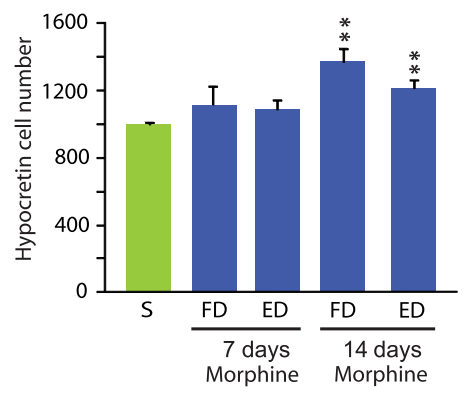

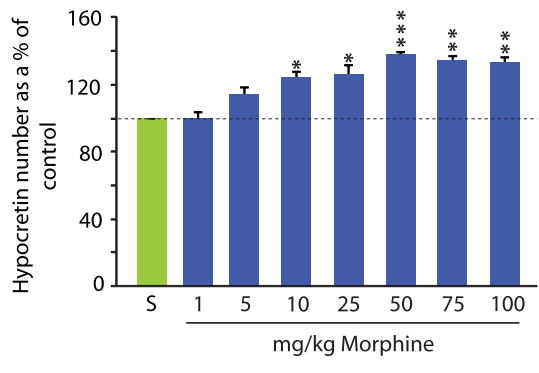

C

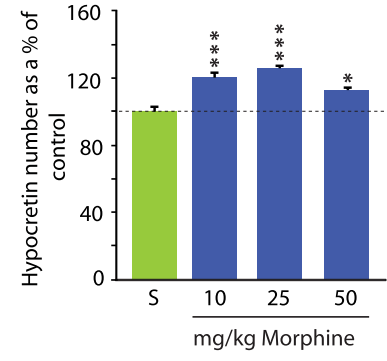

D

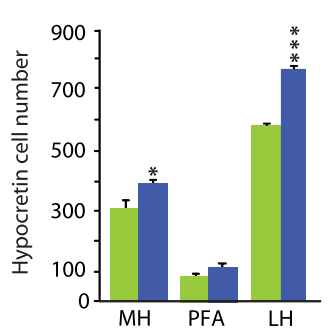

H

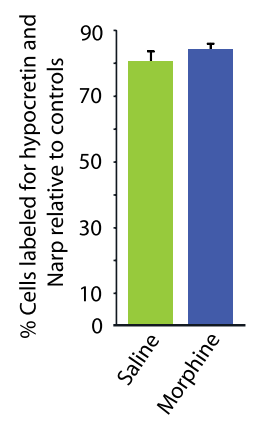

E

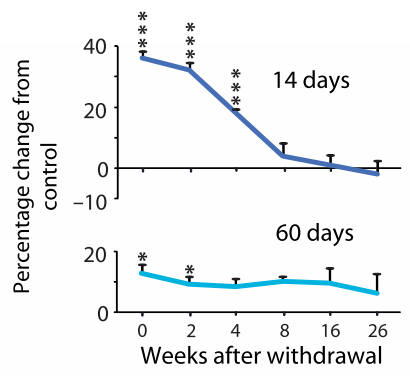

J

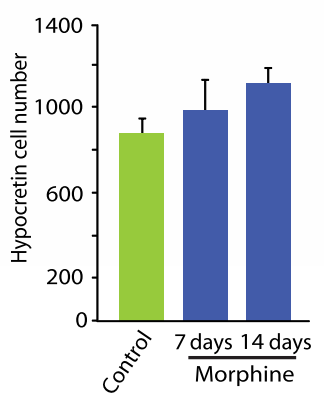

$\mathbf{F}$

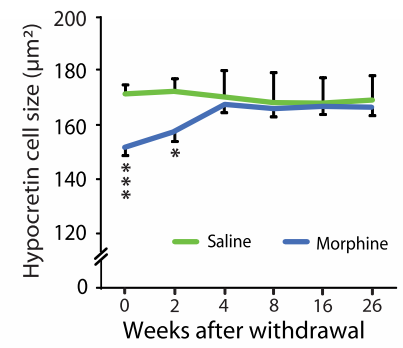

G

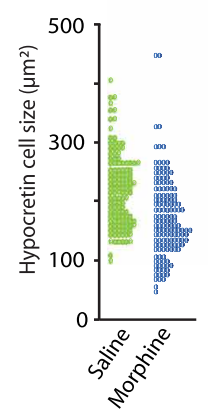

K

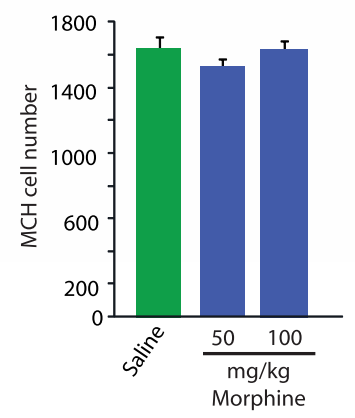

$\mathbf{L}$
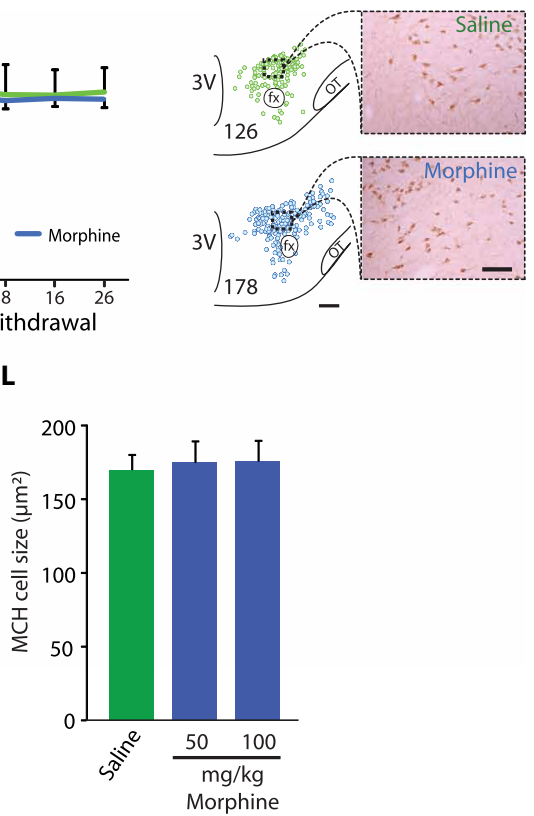

Fig. 2. Dose-dependent effects of morphine administration on hypocretin cells in mouse brain. We administered morphine (blue) or saline (green) to wild-type littermate mice and then stained brain tissue for hypocretin-producing cells. (A) A fixed morphine dose (FD) of $100 \mathrm{mg} / \mathrm{kg}$ for 7 days, or an escalating morphine dose (ED) starting at $100 \mathrm{mg} / \mathrm{kg}$ for 3 days and increasing by $20 \%$ every third day for 7 days, did not significantly increase hypocretin cell number. However, a fixed dose of morphine $(100 \mathrm{mg} / \mathrm{kg})$ for 14 days and an escalating dose for 14 days (with a final dose of $180 \mathrm{mg} / \mathrm{kg}$ ) both increased hypocretin cell number $[P=0.01, t=4.23, \mathrm{df}=4$ and $+22 \%$, $P=0.01, t=4.52, \mathrm{df}=4$ (t test), respectively). (B) Morphine doses of $10 \mathrm{mg} / \mathrm{kg}$ or higher all produced a significantly elevated number of hypocretin neurons compared to saline-injected mice. The elevation in hypocretin cell number at $50 \mathrm{mg} / \mathrm{kg}$ was $38 \%$. Doses above $50 \mathrm{mg} / \mathrm{kg}$ produced no further increase $\left[F_{7,16}=8.1, P<0.001\right.$ (ANOVA)]. (C) Shown are the effects of long-term (60 days) daily administration of morphine at doses of 10,25 , or $50 \mathrm{mg} / \mathrm{kg}$. All three doses produced significant increases in hypocretin cell number as a percentage of control, with the largest increase $(+26 \%)$ observed at a dose of $25 \mathrm{mg} / \mathrm{kg}\left[F_{3,12}=13.5, P<0.001\right.$ (ANOVA)]. (D) Shown is the mediolateral distribution of increased hypocretin cell number after 14 days of morphine administration at $50 \mathrm{mg} / \mathrm{kg}$ in wild-type mice. The elevation of hypocretin cell number was largest in the $\mathrm{LH}$, but the effect was also significant in the $\mathrm{MH}[\mathrm{LH}: P=0.001, t=11.94, \mathrm{df}=7 ; \mathrm{MH}: P=0.05, t=2.44, \mathrm{df}=7$ ( $t$ test)]. PFA, perifornical area. (E) Graph shows the persistence of the elevation of the number of hypocretin neurons after the termination of morphine administration to wild-type mice compared to mice injected with saline (control). Shown is the duration of hypocretin's effects after termination of daily morphine (50 mg/kg) administration starting with the day after the final injection (day 0 of withdrawal) relative to control. After 14 days of morphine administration (top), hypocretin cell number remained significantly elevated for 4 weeks $\left[F_{5,22}=9.4, P<0.001\right.$ (ANOVA)]. After 60 days of morphine administration (bottom), the significant elevation of hypocretin cell number lasted for 2 weeks $\left[F_{5,22}=\right.$ $6.3, P<0.001$ (ANOVA)]. (F) A $12.8 \pm 2.8 \%$ decrease in hypocretin cell size was observed after administration of morphine (50 mg/kg) for 14 days to wild-type mice [significant interaction of treatment and withdrawal $\left(F_{5,58}=5.3, P<0.0005\right)$ ]. After 4 weeks of morphine withdrawal, hypocretin cell size returned to the size seen in saline-treated animals. (G) Representative neurolucida plots and photomicrographs illustrate the increased number and the reduced size of hypocretin cells after 2 weeks of morphine administration at $50 \mathrm{mg} / \mathrm{kg}$ fixed dose. Numbers indicate cell counts in section. Scale bars, $150 \mu \mathrm{m}$ (neurolucida plots) and $50 \mu \mathrm{m}$ (photomicrographs). $3 \mathrm{~V}$, third ventricle. (H) No change was observed in the percentage of cells double-labeled for both hypocretin and Narp in wild-type mice treated with morphine (50 mg/kg) for 14 days compared to control mice injected with saline. (I) We measured the effect of morphine pellet implantation on hypocretin cell number and size compared to control pellets in wild-type mice 72 hours after implantation. On average, cell size was decreased by $23 \%[P=0.001$ (Mann-Whitney $U$ test), $U=5239]$. $n=128$ cells for control saline-injected mouse brain (green), and $n=149$ cells for morphine-injected mouse brain (blue). (J) Shown are the effects of replacement of depleted morphine or control pellets at 3 -day intervals for up to 7 or 14 days to mimic continuous opiate administration. (K and $\mathbf{L})$ In contrast to hypocretin, MCH cell number and size were not affected by administration of morphine at 50 or $100 \mathrm{mg} / \mathrm{kg}$ for 14 days to wild-type mice. Dark green color in (K) and (L) distinguishes MCH neuron comparisons with saline control from hypocretin neuron comparisons with saline control. There was no change in $\mathrm{MCH}$ cell size compared to saline control. ${ }^{*} P<0.05,{ }^{* *} P<0.01,{ }^{* * *} P<$ $0.001, t$ test with Bonferroni correction compared to saline control. 
A

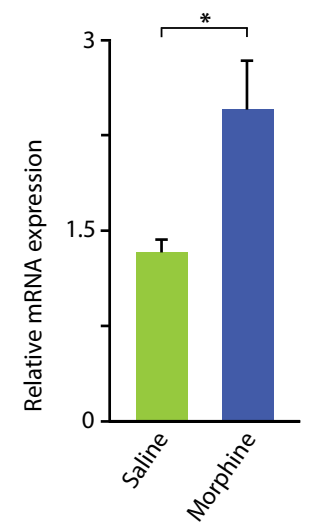

Preprohypocretin

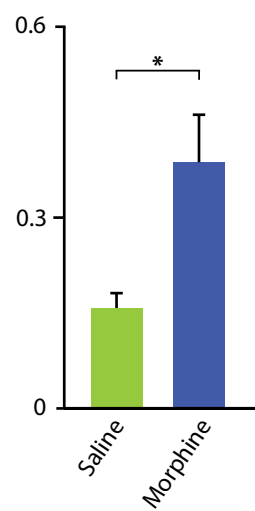

Narp

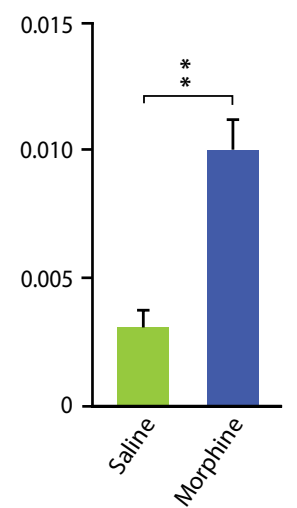

Preprodynorphin

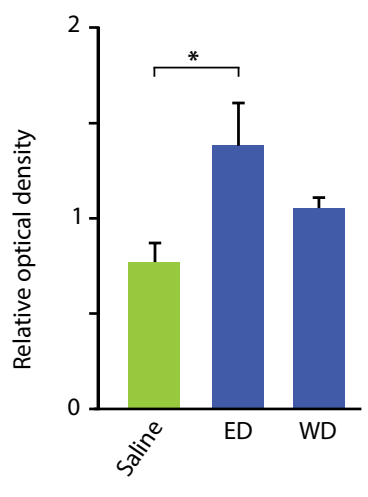

Preprohypocretin

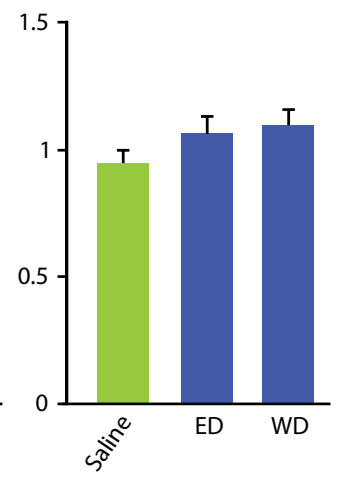

$\mathrm{MCH}$

Fig. 3. Effect of morphine administration on preprohypocretin, preprodynorphin, Narp, and MCH expression in mouse brain. An escalating dose of morphine, starting at $100 \mathrm{mg} / \mathrm{kg}$, was given for 14 days to wild-type mice. QPCR was performed to measure mRNA expression (A to $C$ ), and Western blotting was used to assess the amount of neuropeptide ( $D$ and E). (A to C) An increase in mRNA for preprohypocretin, Narp, and preprodynorphin was observed [preprohypocretin: $P=0.03, t=2.99$, $\mathrm{df}=5$; Narp: $P=0.02, t=3.36, \mathrm{df}=5$ ( $t$ test); preprodynorphin: $P=0.01, t=3.65 \mathrm{df}=5$ ( $t$ test)]. (D) Western blotting showed that 14 days of administration of morphine to wild-type mice increased preprohypocretin by $79 \%[P=0.05, t=2.51, \mathrm{df}=6$ in each group ( $t$ test)] and returned to baseline within 2 weeks. (E) There was no significant change in $\mathrm{MCH}$ after 14 days of morphine administration. The difference remained nonsignificant from control after morphine withdrawal. WD, 2-week withdrawal. ${ }^{*} P<$ $0.05,{ }^{* *} P<0.01, t$ test, compared to saline control.

reaction (qPCR) was performed to measure mRNA amounts in mouse brains of preprohypocretin, Narp, and preprodynorphin (Fig. 3, A to C). Western blotting was used to assess the quantity of preprohypocretin and $\mathrm{MCH}$ peptide in mouse brain (Fig. 3, D and E, and fig. S1). The amounts of mRNAs encoding preprohypocretin, Narp, and preprodynorphin, all found in hypocretin-positive neurons, were found to be elevated [preprohypocretin: $P=0.03$, $t=2.99, \mathrm{df}=5$; Narp: $P=0.02, t=3.36, \mathrm{df}=5$ ( $t$ test); preprodynorphin: $P=0.01, t=3.65, \mathrm{df}=5$ ( $t$ test); Fig. 3 , A to $\mathrm{C}$ ]. Western blot quantitation showed that a 14-day administration of morphine to wild-type mice increased preprohypocretin by $79 \%[P=0.05$, $t=2.51, \mathrm{df}=6$ in each group ( $t$ test)], which returned to baseline within 2 weeks of drug withdrawal (Fig. 3D). Figure 3E shows that there was no significant change in $\mathrm{MCH}$ in the same animals.

\section{Morphine-induced changes in hypocretin cell number are not due to neurogenesis}

Morphine administration at $100 \mathrm{mg} / \mathrm{kg}$ for 14 days to wild-type mice increased the number of hypocretin-producing cells in mouse brains (Fig. 2). However, morphine administration to knockout mice (9) that cannot produce hypocretin did not result in immunohistochemical detection of hypocretin, indicating that the observed immunolabeling after morphine required the presence of hypocretin (Fig. 4A). There was no significant change in the number of 5-bromo- $2^{\prime}$-deoxyuridine (BrdU)-labeled cells throughout the hypocretin neuron region after morphine administration to wild-type mice, indicating that the increased number of hypocretin neurons in response to morphine was not due to neurogenesis (Fig. 4B). Fourteen days of morphine $(100 \mathrm{mg} / \mathrm{kg})$ treatment also did not produce any change in doublecortin staining of neurons in the hypothalamus of mouse brains compared to saline treatment (Fig. 4C, left). Doublecortin staining validity was indicated by a normal labeling pattern in the dentate gyrus (Fig. 4C, right).

\section{Effect of systemic morphine injections on the activity of hypocretin neurons in rats in vivo}

A species-appropriate dose of morphine $(15 \mathrm{mg} / \mathrm{kg})$ resulted in an elevated action potential discharge rate in rat brain hypocretin neurons, accompanied by increased electroencephalographic (EEG) activation and increased electromyographic (EMG) activity in the freely moving rats (Fig. 5). Hypocretin neurons were identified using our previously published criteria (10). Figure 5A shows the discharge rate in rat hypocretin neurons during active waking, quiet waking, non-rapid eye movement (REM) sleep, and REM sleep and after morphine injection in waking animals (averaged across five neurons recorded in three rats). Hypocretin neurons displayed an elevated discharge rate after morphine administration comparable to that during active waking and greater than that during quiet waking, non-REM sleep, and REM sleep [one-way ANOVA for hypocretin neurons: $n=5, F_{4,16}=18.2, P<0.0001$; post hoc comparisons with Tukey/Kramer procedure: active and quiet waking, $P<0.05$; active waking and non-REM/REM sleep, $P<0.01$; morphine administration: active waking, quiet waking, non-REM sleep, and REM sleep, all $P<0.01]$. Figure 5B shows recordings of the discharge rate in discharges per second, muscle tone, and EEG data (expansions enable better visualization of the time course and an action potential waveform, used to aid in identification of hypocretin neurons; recording sites are indicated in Fig. 5C by black arrowheads).

\section{Reversal of decreased hypocretin cell number in narcoleptic mice after morphine administration}

We used a newly developed transgenic mouse model in which hypocretin cell loss is triggered by doxycycline (DOX) withdrawal, the orexin-tTA; TetO diphtheria toxin A (DTA) mice (henceforth called DTA mice) (11). This transgenic mouse model allows induction of selective hypocretin cell loss and symptoms of narcolepsy with cataplexy in adult DTA mice after DOX withdrawal, resembling the syndrome that occurs in human narcolepsy. Resuming DOX 
A
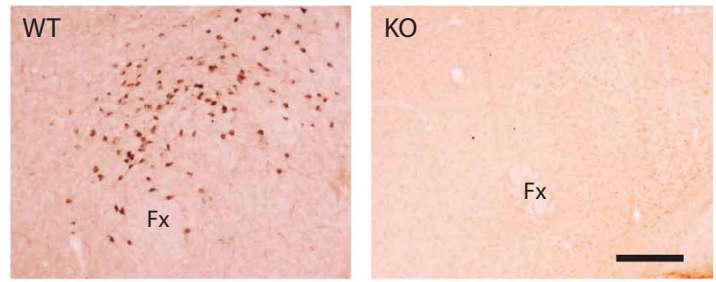

B
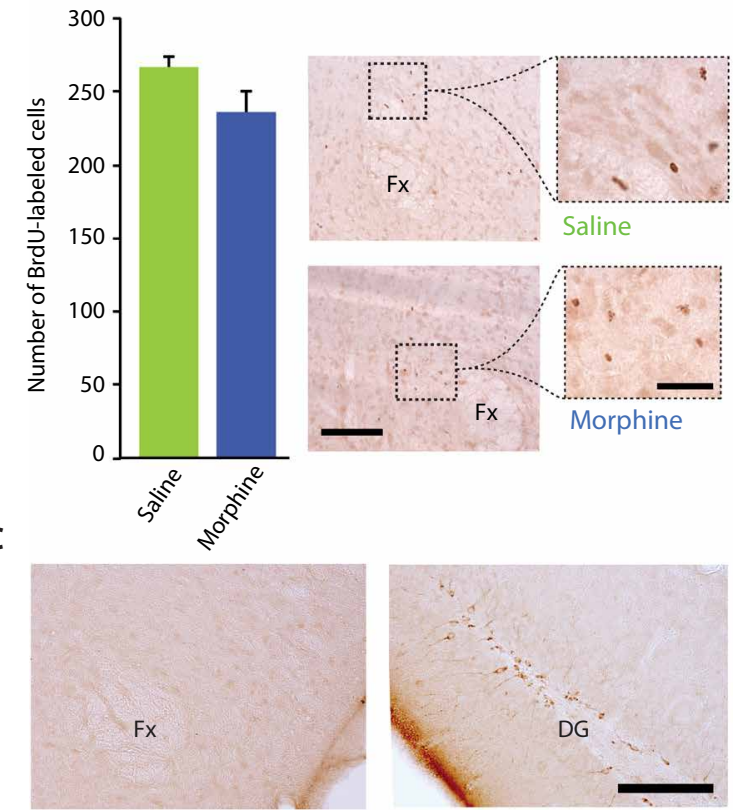

Fig. 4. The increase in hypocretin cell number after morphine administration was not due to neurogenesis. (A) Morphine administration at $100 \mathrm{mg} / \mathrm{kg}$ for 14 days resulted in labeling of hypocretin cells in wild-type (WT) mice, but not in hypocretin knockout $(\mathrm{KO})$ mice, indicating that labeling required the presence of hypocretin in neurons. Scale bar, $200 \mu \mathrm{m}$. (B) The increased number of hypocretin neurons after morphine administration was not due to neurogenesis. BrdU labeling to identify new neurons showed no significant increase in the number of new hypocretin neurons after 14 days of morphine $(100 \mathrm{mg} / \mathrm{kg})$ treatment of wild-type mice compared to control mice given saline injections. Right: BrdU-labeled cells in the perifornical area of saline-treated (top) and morphine-treated (bottom) animals. Scale bars, 100 and $40 \mu \mathrm{m}$. (C) Shown is immunohistochemical staining in the hypothalamus for doublecortin after 14 days of morphine $(100 \mathrm{mg} / \mathrm{kg})$ treatment of wild-type mice. Left: Representative photomicrograph shows the absence of doublecortin staining in the hypothalamus of a morphine-treated animal. Right: Representative photomicrograph shows normal doublecortin staining of dentate gyrus (DG) of the same animal. Scale bar, $100 \mu \mathrm{m}$.

administration stops further hypocretin cell loss in the DTA mice. Control mice were DTA mouse littermates maintained on DOX throughout the experiment. The dashed horizontal red line in Fig. 6A shows the number of hypocretin cells in DTA littermate control mice maintained on DOX and administered daily saline injections for 14 days. The green bar shows littermate DTA mice subjected to DOX withdrawal for 1.5 days, followed by restoration of DOX administration and saline injections for 14 days. A 30\% reduction in hypocretin cells relative to the number of hypocretin cells in control DTA mice maintained on DOX was observed
(Fig. 6A). However, when daily morphine $(100 \mathrm{mg} / \mathrm{kg})$ injections were given instead of saline injections for 14 days in the experimental group, the number of hypocretin cells detected by immunohistochemistry was restored to baseline [blue bar; $P=0.0003, t=6.31$, $\mathrm{df}=4(t$ test $)]$. Figure $6 \mathrm{~B}$ shows the effect of morphine administration on cataplexy in two groups of four hypocretin cell-depleted DTA mice. DOX treatment was halted for 18 days, a duration that produces a $95 \%$ depletion of hypocretin neurons and cataplexy. Morphine treatment given at a dose of $50 \mathrm{mg} / \mathrm{kg}$ for 1 or 2 weeks reduced cataplexy relative to control untreated mice [treatment effect, $F_{1,6}=148.4, P=0.0001$ (ANOVA)]. Hypocretin knockout mice, in which the hypocretin neurons are present but the peptide is absent from birth, show much lower amounts of cataplexy than do DTA mice. Therefore, the effects of morphine administration on hypocretin knockout mice could not easily be tested. The extensive loss of most of the hypocretin cell bodies in the DTA mice more closely resembles the characteristics of human narcolepsy than does the lack of hypocretin neuron production in hypocretin knockout mice.

Figure 6C shows the number of hypocretin-producing cells in three human control subjects without narcolepsy (green) and in two patients with narcolepsy. In contrast to our prior studies of $40-\mu \mathrm{m}$ sections of frozen human brain tissue analyzed by stereology (5), brain tissue of all five subjects was preserved in paraffin, was sectioned at $6-\mu \mathrm{m}$ intervals, and was counted with an automated counting procedure. Both patient NBB-01064 and patient NBB-08023 were diagnosed as having narcolepsy with cataplexy. Patient NBB01064 was chronically treated with morphine for relief of her pain resulting from discopathy after her initial narcolepsy diagnosis. Patient NBB-08023 was not treated with opiates. Eight years later, patient NBB-01064 was reclassified as having idiopathic hypersomnia without cataplexy, an unusual clinical course, suggesting that the extended period of morphine administration may have changed the trajectory of the disease. Figure 6C shows hypocretin cell counts in the diagnosed narcoleptic patients with cataplexy: without morphine treatment (NBB-08023) and with morphine treatment (NBB-01064). The morphine-treated patient (NBB-01064) had 16\% the number of hypocretin cells found in healthy controls compared to $3 \%$ for the narcoleptic with cataplexy patient not treated with morphine (NBB-08023).

\section{DISCUSSION}

Cells with different neurotransmitter phenotypes have been characterized by various techniques since the early work of Falck et al. (12). Most current research studies use immunohistochemistry, the most sensitive technique, to identify and quantify these cell types in brain tissue representing normal and pathological human conditions. Hypocretin cell counts determined by immunohistochemistry (5) exceed those determined by genetic labeling (13) and RNA labeling (14). A relevant comparison is between our initial finding of an average of 71,000 hypocretin cells in human control brain tissue, with a $90 \%$ loss of these cells in brain tissue from patients with narcolepsy/cataplexy using immunohistochemistry $(5,15)$, and a contemporaneous report of 15,000 to 20,000 hypocretin cells in normal human control brain tissue and no detected hypocretin cells in patients with narcolepsy/cataplexy using in situ labeling (14). An independent study confirmed our immunohistochemistry work (Fig. 6C), finding surviving hypocretin cells in the brains of all human narcoleptic patients studied (16). 


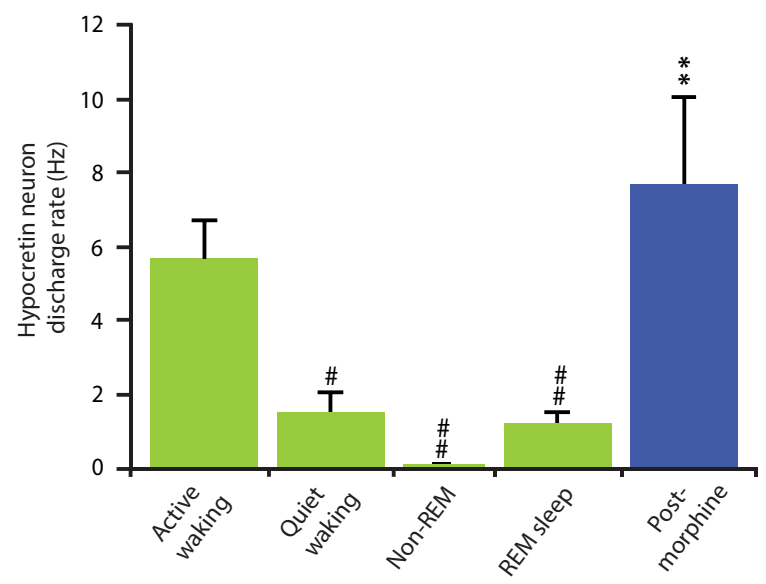

C

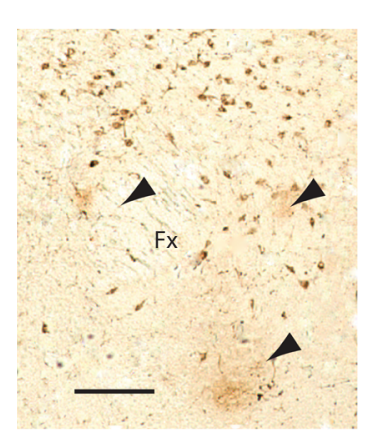

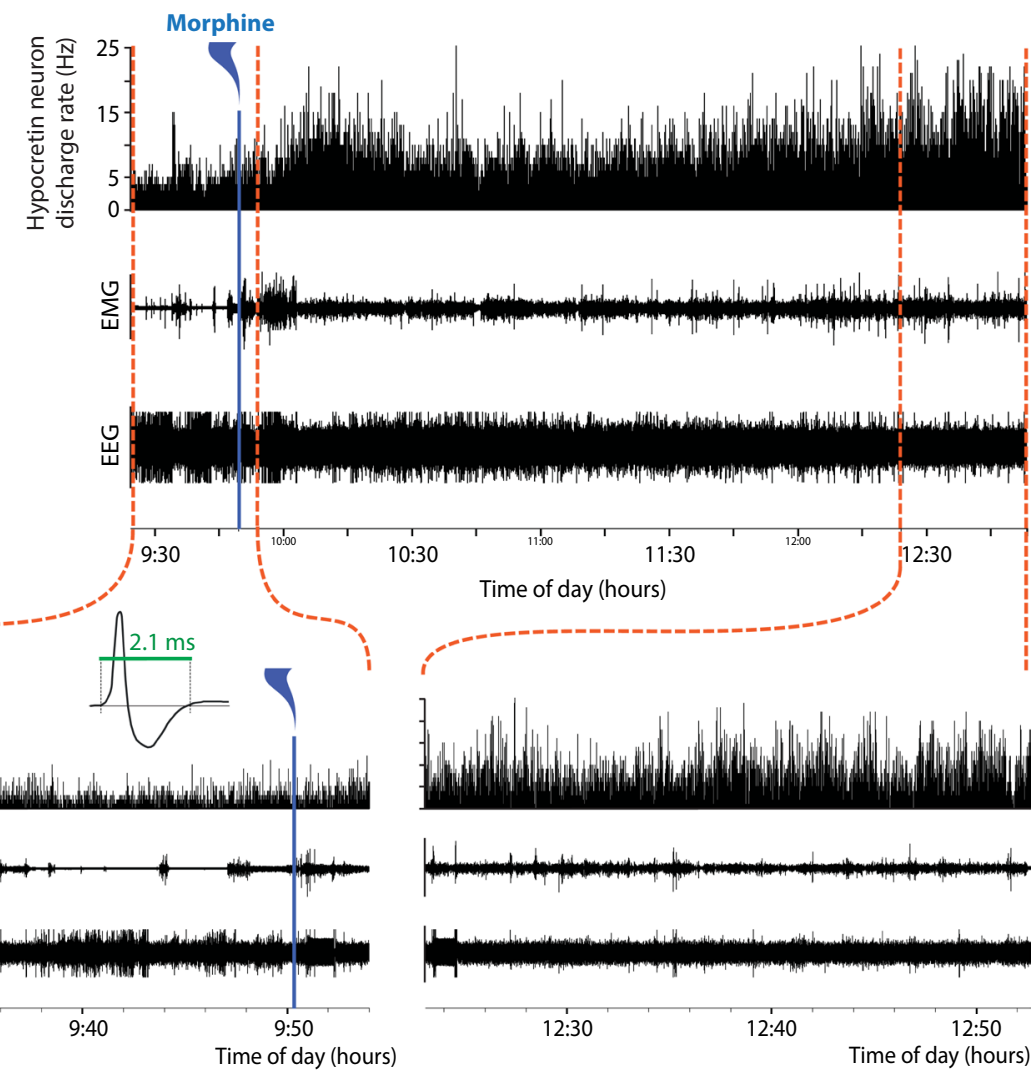

Fig. 5. Effect of morphine administration on hypocretin cell activity in rats in vivo. A species-appropriate dose of morphine (15 mg/kg) injected into three freely moving rats resulted in an elevated neuronal discharge rate lasting for 3 hours accompanied by an increase in EMG activity. (A) Sleep rates are averages of mean rate determined by five 10-s samples in each of five hypocretin neurons from three rats in each sleep state: active waking, quiet waking, non-REM sleep, and REM sleep. Post-morphine injection rate was based on five 10-s samples in each neuron taken $15 \mathrm{~min}$ after morphine injection. One-way ANOVA of hypocretin neurons $(n=5): F_{4,16}=$ 18.2, $P<0.0001$. Post hoc comparisons with Tukey/Kramer procedure: active waking/quiet waking, $P<0.05$; active waking/non-REM sleep, $P<0.01$; active waking/REM, $P<0.01$. (B) Discharge rate of rat hypocretin neurons after morphine administration. Bottom: Traces show EEG activation immediately after morphine injection (left) and 3 hours after injection (right). Increased rate of discharge in hypocretin neurons lasted for 3 or more hours after injection of morphine. Expanded traces show the characteristic long average waveform of hypocretin neurons. (C) Histology showing three recording sites of hypocretin neurons in rat brain, labeled with arrowheads. Scale bar, $150 \mu \mathrm{m} .{ }^{\#} P<0.05,{ }^{\# \#} P<0.01$, compared to active waking; ${ }^{* *} P<0.0001$ compared to quiet waking, non-REM sleep, and REM sleep.

Immunohistochemistry can be combined with the measurement of immediate early gene expression (4) or with juxtacellular labeling and unit recording (10) to characterize the activity of identified cells in the brains of normal animals. Immunohistochemistry is also used to identify and study neuropathologies, including cell loss in narcolepsy, Huntington's disease, Parkinson's disease, Alzheimer's disease, and other disorders. Our findings in the current study suggest that this approach may be missing an important aspect of brain function. Under some drug administration or disease conditions, the number of cells of a particular phenotype visualized with immunohistochemistry can change. A decrease in the number of cells can mistakenly be interpreted as representing neuronal death. However, increases of the sort we report here and that we and others have reported previously $(17,18)$ suggest that a portion of certain cell types do not produce immunohistochemically detectable amounts of their neurotransmitter under most conditions but can be induced to produce such amounts by drugs or perhaps by disease.
In recent work, we have shown that increasing hypocretin content by inhibiting microtubule polymerization with colchicine in mice increases the number of hypocretin cells detected by immunohistochemistry by as much as $40 \%$ in wild-type mice (19), similar to the amount we now see in mice after opiate administration. This raises the question of the extent to which the reduced number of hypocretin cells that characterizes human narcolepsy and other disorders may, at least partially, be due to reduced production of hypocretin in a subpopulation of hypocretin cells rather than the loss of hypocretin-producing cells through neuronal death. In mice given colchicine, the size of the hypocretin cells increases, possibly as a result of inhibition of axonal transport (16). One may speculate that the increased activity that we see in hypocretin neurons in mice after morphine administration has the opposite effect on cell size as colchicine administration. The action potentials associated with activation after morphine administration may cause hypocretin and other neuropeptides such as Narp and dynorphin to be transported 


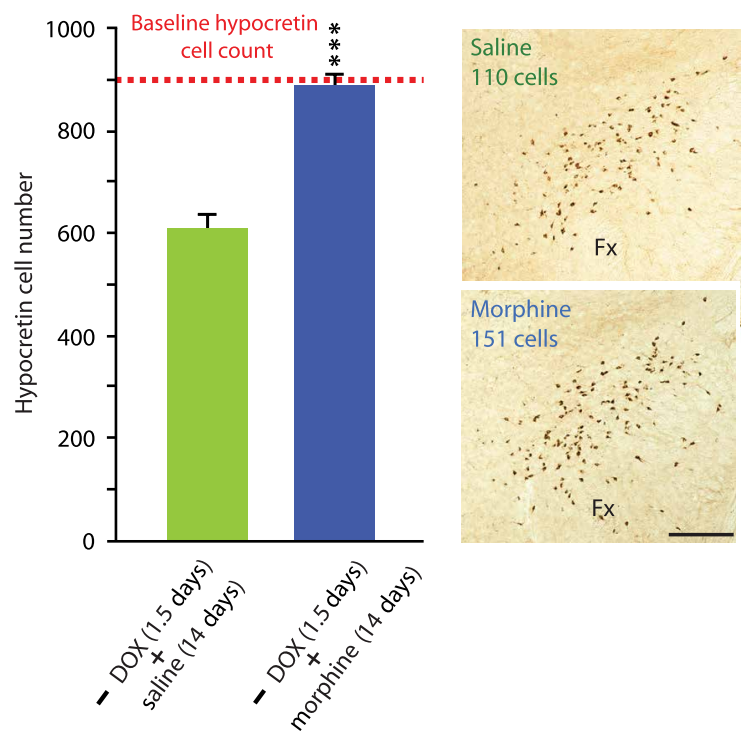

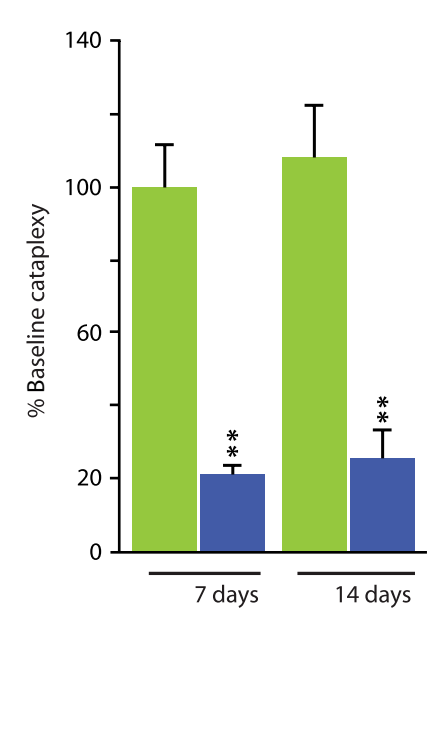

C

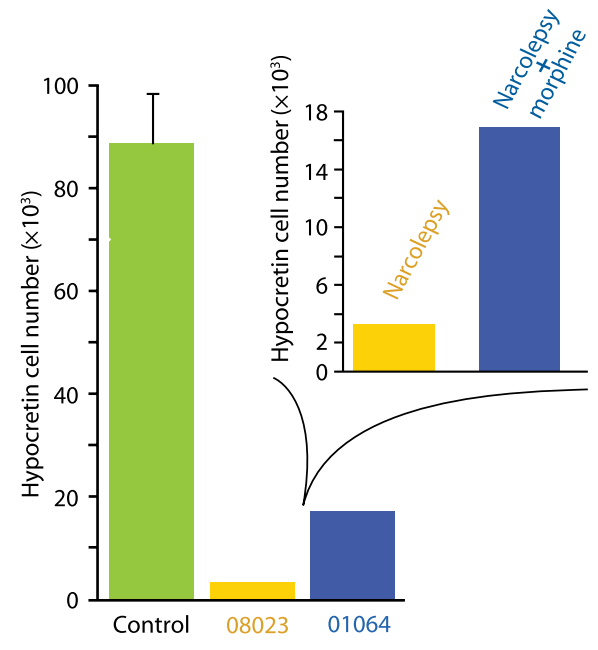

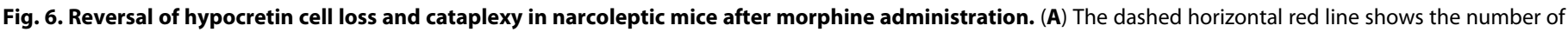

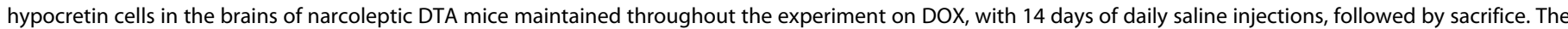

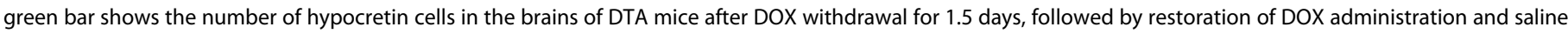

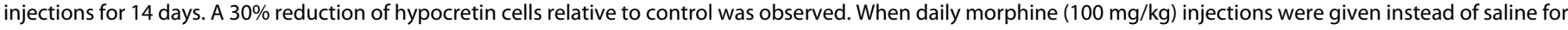

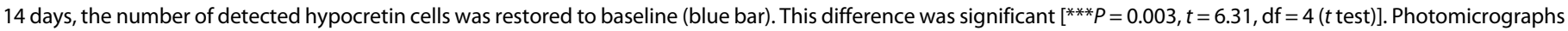

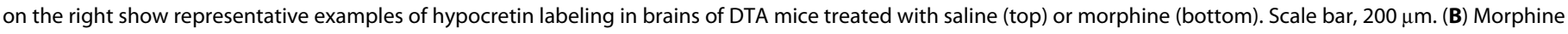

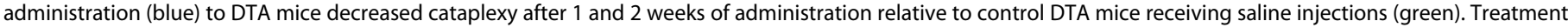

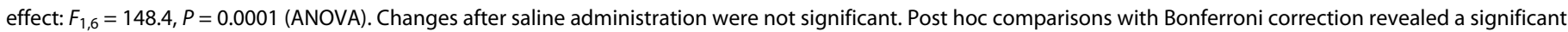

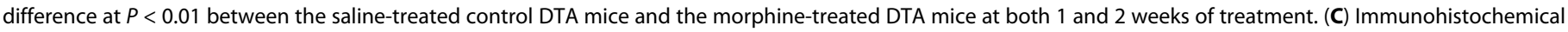

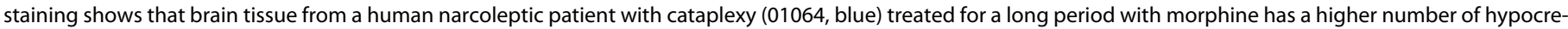

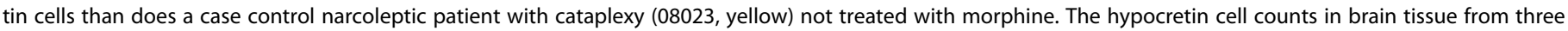

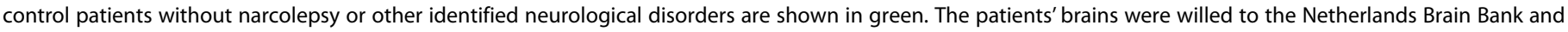
preserved and analyzed using the same techniques (Table 1).

out of the neurons and down axons faster than they can be synthesized, depleting the substrates and leading to shrinking of the cells.

Our work reported here shows that additionally recruited neurons after morphine administration in mice may not be uniformly distributed across the population of hypocretin cells. Further work will determine whether these neurons receive a different pattern of inputs, project to a different pattern of sites, or differ in other ways from the neuronal populations observed before opiate administration.

We show that the increased number of hypocretin neurons caused by morphine administration in mice was not due to neurogenesis. We also demonstrate that the increase in number lasted beyond the period when opiates would be readily detectable in the tissues of the mice. In mice, the time course of hypocretin cell number increase and cell size decrease differed. The increase required at least 2 weeks of highdose morphine administration and returned to baseline by 8 weeks after administration. However, the cell size reduction in the same mice occurred within as little as 72 hours of morphine exposure, with hypocretin cell size returning to baseline by 4 weeks after morphine treatment. Morphine decreases the size of ventral tegmental area (VTA) neurons in rodents (20). Although a major increase (or decrease) in cell number of any neuronal group has not, to our knowledge, been reported with heroin or morphine administration in other studies, opiates have been shown to produce changes in dendritic field and spine morphology in the ventral tegmental field and nucleus accumbens, which may reflect altered release of dopamine from VTA cells (21).
We (4) and others (2) have demonstrated that increased hypocretin cell activity is linked to pleasurable but not to aversive tasks in mice and rats. We have found that hypocretin is released in nonaddicted humans when they are engaged in enjoyable tasks but not when they are aroused by pain or feeling sad (3). Conversely, human narcoleptic patients, who have, on average, a $90 \%$ loss of detectable hypocretin cells (5), show increased depression and are relatively resistant to drug addiction (22). In opiate addicts, elevating hypocretin production for long periods by self-administration of drug may create a positive mental state (affect), and a more negative affect is likely upon withdrawal of drug. This feedback loop may contribute to, or underlie, drug addiction.

Dopamine neurons, particularly those located in the VTA, have been strongly implicated in reinforcement in general and addiction in particular. Hypocretin and dopamine are evolutionarily linked from both a neurochemical and an anatomical perspective (23). The VTA receives a major hypocretin projection and projects to the nucleus accumbens. The amounts of dopamine and its major metabolites in the nucleus accumbens are markedly increased by the microinjection of hypocretin-1 and hypocretin-2 into the VTA. An intra-VTA injection of a selective hypocretin receptor-1 antagonist, SB334867A, suppresses morphine-induced place preference. Dopaminergic activation of neurons in the nucleus accumbens shell by morphine withdrawal requires the integrity of hypocretin receptor-1 (24). 
An in vitro brain slice study found that opioids decrease the activity of hypocretin neurons and that blockade of $\mu$-opioid receptors enhances the activity of hypocretin neurons. Morphine pretreatment inhibited subsequent excitatory responses to hypocretin in hypocretin neurons recorded in vitro (21). However, our current in vivo data show that systemic administration of morphine increased hypocretin neuron activity in rats, an effect presumably mediated at the neural circuit level, and therefore, this effect would not be seen in brain slices. Activation of hypocretin neurons reinstates an extinguished preference for morphine in a rodent study (25).

The VTA, nucleus accumbens, amygdala, locus coeruleus, and central gray matter all have been implicated in reward mediation (26). Hypocretin cells also contain and release glutamate (27), trigger glutamate release from adjacent cells, and show Narp, an immediate early gene encoding a protein involved in aggregating AMPA receptors and thought to have a role in addiction (8). Bingham et al. (28) found that hypocretin, like morphine, produces profound analgesia. Aston-Jones et al. (29) showed that hypocretin was required for learning a morphine-conditioned place preference task. Georgescu et al. (30) showed that hypocretin neurons, but not nearby $\mathrm{MCH}$ neurons, express $\mu$-opioid receptors. Cyclic adenosine $5 '$-monophosphate response element-mediated transcription is induced in a subset of hypocretin cells, but not in $\mathrm{MCH}$ cells, after chronic exposure to morphine or induction of morphine withdrawal. In addition, c-Fos and the preprohypocretin gene are induced in hypocretin cells during morphine withdrawal. Constitutive hypocretin knockout mice develop attenuated morphine dependence, indicated by a less severe antagonist-precipitated withdrawal syndrome (24).

It has long been anecdotally noted that narcoleptic patients, who have, on average, a 90\% loss of hypocretin neurons (5), show little, if any, evidence of drug abuse or addiction, despite their daily prescribed use of gamma hydroxybutyrate, methylphenidate, and amphetamines, drugs that are frequently abused. These data are consistent with our current finding of increased hypocretin cell populations in human heroin addicts, perhaps facilitating and maintaining addiction. The reduced number of hypocretin neurons in patients with narcolepsy may be related to the lack of drug addiction in these patients.

Our study has several limitations. The first is that we were unable to determine the difference in the dynamics of the hypocretin cell increase in humans and mice and the return to baseline after opiate withdrawal. Of particular interest were the duration of increase in the population of detected hypocretin neurons after cessation of opiate administration and whether it correlated with opiate craving in humans. Our discovery of tissues from a narcoleptic patient given morphine for pain management, a control narcoleptic patient not given such treatment, and neurologically normal control subjects, with all tissues preserved and analyzed in the same manner at the same brain bank, was unusual. This situation is highly unusual because there are so few postmortem brains from narcoleptic patients in brain banks and fewer still where the narcoleptic patients have been given long-term opiate treatment. Another limitation of our study is that we do not yet know the mechanisms responsible for the sustained increase in hypocretin cells that we see in the mice and in human heroin addicts. The DTA mouse model may make elucidating the mechanisms underlying this increase possible.

In 1981, a report of a narcoleptic patient given codeine (a natural isomer of methylated morphine) for the control of Crohn's disease symptoms described a "disappearance of his narcolepsy, cataplexy, sleep paralysis, and hypnagogic hallucinations" (31). In a second case report, a narcoleptic patient, who could not continue taking stimulant drugs because of coronary artery disease and the necessity for kidney dialysis, urged his doctor to prescribe codeine for his narcolepsy because of the reversal of narcoleptic symptoms he had previously experienced when given codeine for pain. His physician published the results indicating a "dramatic improvement in alertness and substantial reduction of cataplexy," the defining symptoms of narcolepsy (32). A third paper (33) tested codeine on eight narcoleptic patients. Sleep diaries and patient reports revealed consistent symptom improvement compared to placebo; however, there were no significant differences in the multiple sleep latency tests (cataplexy was not tested for). This ambiguous result from a 1 -week trial in three human patients appears to have ended opiate use for treatment of narcolepsy. In human studies, separating the placebo effect from the drug effect and from drug-seeking behavior can be difficult. We now show (Fig. 6B) that opiate treatment is effective in reducing or eliminating cataplexy in a mouse model of narcolepsy.

It is possible that, with the appropriate schedule of administration and dosage, opiate agonists might be an effective treatment for human narcolepsy. However, tests to determine the dose of opiate agonist with the least addictive potential and maximal safety and effectiveness would be required before any recommendation for opiate use in human narcoleptic patients. The autonomic effects of effective opiate agonist doses would need to be determined. An alternate approach might be to develop agonists that more specifically increase the number of hypocretin-producing neurons and thereby increase hypocretin production without the risks of more widespread neuronal activation. The development of appropriate transgenic mice would be an important step in this direction. One may also speculate that reducing the number of neurons producing detectable amounts of hypocretin to the level seen in nonaddicted human controls or reducing hypocretin action pharmacologically using opiate receptor antagonists might be a potential strategy for treating opiate addiction in humans.

\section{MATERIALS AND METHODS Study design}

Immunohistochemistry was used to stain for hypocretin in human brain tissue from neurologically normal control individuals, heroin addicts, and patients with narcolepsy (Table 1). Human brain tissue was obtained from the National Neurological Research Specimen Bank (Los Angeles), the Eunice Kennedy Shriver National Institute of Child Health and Human Development Brain Bank, and the Netherlands Brain Bank (Table 1). Parallel studies were done in wild-type mice and in a mouse model of narcolepsy in which selective hypocretin cell loss in mature animals was triggered by intracellular expression of diphtheria toxin (DTA mice) in response to removal of mice from a DOX diet. These mice simulate the consensus understanding of the cause, developmental timing, and symptoms of human narcolepsy. The amount of mRNA and neuropeptides and the activity of hypocretin neurons were measured in the mice. The age and sex of mice used in each study are described in table S1. Morphine and control saline injections were performed at the same time in experimental and control groups. All tissue analyses were performed by experimenters blinded to treatment conditions. 


\section{Human hypothalamic tissue}

The hypothalamus of five addicts, one morphine-treated narcoleptic with cataplexy, one narcoleptic with cataplexy patient not given morphine, and nine control brains was examined for this study. Characteristics of addicts, narcoleptics, and control subjects are summarized in Table 1. Five heroin addict and seven control brains were fixed in $10 \%$ buffered formalin containing $0.1 \mathrm{M}$ phosphate buffer ( $\mathrm{pH}$ 7.4). The hypothalamus was cut into $40-\mu \mathrm{m}$ sections. Sections were immunostained for hypocretin (orexin-A) and $\mathrm{MCH}$. Adjacent sections were Nissl-stained. Human nuclear divisions are according Mai et al. (34). Two narcoleptic and three control brains were paraffin-embedded. Their sectioning and treatment are explained below.

\section{Immunostaining for hypocretin and $\mathrm{MCH}$ in brain tissue from heroin addicts and control subjects}

Immunostaining for hypocretin and $\mathrm{MCH}$ in $40-\mu \mathrm{m}$ sections of frozen tissue was performed as in our earlier reports $(5,7)$. The sections were treated with $0.5 \%$ sodium borohydride in phosphate-buffered saline (PBS) for $30 \mathrm{~min}$, washed with PBS, and then incubated for 30 min in $0.5 \% \mathrm{H}_{2} \mathrm{O}_{2}$ for blocking of endogenous peroxidase activity. For antigen retrieval, sections were heated for $30 \mathrm{~min}$ at $80^{\circ} \mathrm{C}$ in a water bath with $10 \mathrm{mM}$ sodium citrate $(\mathrm{pH}$ 8.5) solution. The sections were cooled to room temperature in sodium citrate and washed with PBS. After thorough washing with PBS, the sections were placed for 2 hours in 1.5\% normal goat serum in PBS and incubated for 72 hours at $4^{\circ} \mathrm{C}$ with a 1:10,000 dilution of Hcrt-1 (Rabbit Anti-Orexin A, H-003-30, Phoenix Pharmaceuticals Inc.). Sections were then incubated in a secondary antibody (biotinylated goat antirabbit immunoglobulin G, Vector Laboratories), followed by avidinbiotin-peroxidase complex (ABC Elite Kit, Vector Laboratories), for 2 hours each at room temperature. The tissue-bound peroxidase was visualized by a diaminobenzidine $(\mathrm{DAB})$ reaction (Vector Laboratories). Adjacent series of sections were immunostained for $\mathrm{MCH}$ (with a 1:20,000 polyclonal rabbit anti-MCH; H-070-47, Phoenix Pharmaceuticals Inc.). In all cases, the sectioning and staining were done blind to condition, with the same antibody lots used for all subgroups in each study.

\section{Double labeling of neurons for hypocretin and Narp}

After blocking using 3\% normal donkey serum and $0.3 \%$ Triton X, sections were incubated with hypocretin antibody (orexin 1:1000, anti-goat; 8070, Santa Cruz Biotechnology) and Narp (1:1000; antirabbit, Worley laboratory, Johns Hopkins) for 72 hours. The secondary antibodies, Alexa Fluor 488 anti-goat (1:400) and Alexa Fluor 568 anti-rabbit (1:400) (Invitrogen, Life Technologies Corporation), were used.

\section{Quantitative analysis}

Hypocretin and $\mathrm{MCH}$ cell number, distribution, and size were determined in human brain tissue using stereological techniques on a 1-in-12 series of 40- $\mu \mathrm{m}$ sections through the complete hypothalamus. We used a Nikon E600 microscope with three-axis motorized stage, video camera, Neurolucida interface, and Stereo Investigator software (MicroBrightField Corp.). Quantification of hypocretin and Narp double labeling were carried out using Zeiss Axio Imager M2. In human subjects, the complete hypothalamic region of one-half of the human brain was cut into $40-\mu \mathrm{m}$-thick coronal sections using a one-in-six section interval for each series. One series of sections were stained with cresyl violet for the localization of anatomical regions. Adjacent series of sections were immunohistochemically stained for hypocretin. After staining, the sections were serially arranged and mounted on slides. Hypocretin cells were individually counted with the Neurolucida program. The final number reported is the number for the whole brain based on our systematic count. Sectioning, staining, and counting were done by investigators blind to condition. In our initial human studies $(5,7)$, we confirmed the results of stereological sampling with exhaustive counting of hypocretin neurons. In mice, we completely counted bilaterally the number of hypocretin neurons on a one-in-three series and reported the resulting number without multiplying by 3 .

\section{Hypocretin immunostaining in narcoleptic and control brain tissue (paraffin-fixed tissue)}

Sections cut at $6 \mu \mathrm{m}$ were incubated with rabbit anti-hypocretin A antibody (catalog no. H-003-30, Phoenix Pharmaceuticals Inc.) at 1:20,000 diluted in tris-buffered saline (TBS)-milk [5\% (w/v) milk in $0.05 \mathrm{M}$ tris and $0.15 \mathrm{M} \mathrm{NaCl}(\mathrm{pH} \mathrm{7.6)]} \mathrm{for} \mathrm{an} \mathrm{hour} \mathrm{at} \mathrm{room}$ temperature, followed by incubation overnight at $4^{\circ} \mathrm{C}$. The next day, after rinsing in TBS, sections were incubated with goat anti-rabbit serum at 1:400 in TBS for 1 hour at room temperature. Antibody binding was visualized according to the $\mathrm{ABC}$ method at a 1:800 dilution of these complexes in TBS for 1 hour at room temperature. After rinsing in TBS, staining was developed by DAB and nickel ammonium sulfate for about $20 \mathrm{~min}$. Reactions were stopped by washing sections in distilled water. Finally, slides were dehydrated in an ascending series of alcohol and coverslipped in xylene with Entellan.

\section{Counting procedure for paraffin sections}

Only positively stained neurons containing a nucleolus were included to prevent double counting. This counting procedure, which was judged to be the best for the thin $(6 \mu \mathrm{m})$ sections used, is based on the principle that nucleoli can be considered as hard particles that will not be sectioned by a microtome knife but, instead, are pushed either in or out of the paraffin when hit by the knife (35). All the cell counts were from one side of the hypothalamus. Completeness of the cell counting was confirmed by graphically presenting the actual number of neurons counted in every section from rostral to caudal to review the distribution pattern. If the most rostral or caudal sections still showed positive cells, we cut the remaining tissue so as to have a complete series. Following hypocretin staining, the total number of neurons was counted at $600-\mu \mathrm{m}$ intervals throughout the area. In each section, all hypocretin neurons with their typical cell profiles and a visible nucleolus serving as a unique marker for each neuron were counted using light microscopy at a magnification of $400 \times$. Taking into account the interval distances between individual sections, the total number of hypocretin neurons was determined on the basis of the Cavalieri principle (36).

\section{Animal study}

All procedures were approved by the Institutional Animal Care and Use Committee of the University of California at Los Angeles and the Veterans Administration Greater Los Angeles Healthcare System.

\section{Morphine pellet study in mice}

Experiments were performed on male C57BL/6 mice weighing 25 to $30 \mathrm{~g}$. Animals were housed on a 12-hour light-dark cycle. Food and water were available ad libitum. The characteristics in each group of 
the study are detailed in table $\mathrm{S} 1$. Morphine $(25 \mathrm{mg})$ pellets [from the National Institute on Drug Abuse (NIDA)] and placebo pellets (NIDA) were subcutaneously implanted with isoflurane anesthesia. There were three groups for the pellet study: (1) pellet implanted for 3 days, (2) pellet implanted for 7 days, and (3) pellet implanted for 14 days. For groups 2 and 3, the initial pellet was replaced after 72 hours. All animals were sacrificed between 12:00 p.m. and 2:00 p.m. Animals were anesthetized intraperitoneally (i.p.) with Fatal-Plus solution and then perfused transcardially with PBS, followed by $4 \%$ paraformaldehyde in PBS. Brains were removed and post-fixed for 72 hours in $4 \%$ paraformaldehyde in PBS, followed by $30 \%$ sucrose in PBS. The sections were cut at $40 \mu \mathrm{m}$ on a sliding microtome and stained for hypocretin as described earlier. Mouse nuclear divisions are as in McGregor et al. (4).

\section{Morphine dose response in mice}

A 14-day dose-response trial with daily administration of a fixed dose of morphine (morphine sulfate injection USP, Hospira Inc.) in each group of animals from 1 to $100 \mathrm{mg} / \mathrm{kg}$ body weight was conducted. The doses were 1, 5, 10, 25, 50, 75, and $100 \mathrm{mg} / \mathrm{kg}$. Control groups received saline injections. The morphine escalating dose started with $100 \mathrm{mg} / \mathrm{kg}$ daily and was increased by $20 \%$ every 72 hours. For the 60-day dose-response trial, there were three doses: 10, 25, and $50 \mathrm{mg} / \mathrm{kg}$ body weight. Control groups received saline. Injections were done at 10:00 a.m. in mice on a 12-hour/12-hour cycle with light onset at 7:00 a.m. All animals were sacrificed between 12:00 p.m. and 2:00 p.m.

\section{Morphine $(50 \mathrm{mg} / \mathrm{kg})$ for 14 days and withdrawal for up to 6 months}

To study the effect of morphine withdrawal on hypocretin neurons, we administered $50 \mathrm{mg} / \mathrm{kg}$ for 14 days to the mice. The control group received saline. Two-week, 4-week, 8-week, 16-week, and 26-week withdrawal durations were used.

\section{Morphine $(50 \mathrm{mg} / \mathrm{kg})$ for 60 days and withdrawal up to 6 months}

To study the effect of long-duration administration of morphine, we gave $50 \mathrm{mg} / \mathrm{kg}$ for 60 days. The control groups received saline. Two-week, 4-week, 8-week, 16-week, and 26-week withdrawal durations were used.

\section{Investigation of neurogenesis after morphine treatment in mice}

To look for evidence of neurogenesis after morphine treatment, BrdU was given intraperitoneally at $50 \mathrm{mg} / \mathrm{kg}$ in sterile saline once daily for 2 weeks. BrdU injection was done in morphine-treated $(100 \mathrm{mg} / \mathrm{kg})$ and saline-treated animals. Morphine injection was done in the morning, and BrdU injection was done in the evening for the 2 -week period. Animals were sacrificed 2 weeks after the initial injection or 4 weeks after the end of 2 weeks of injection period. There were three animals in each experimental group.

\section{Immunohistochemistry (40- $\mu \mathrm{m}$ sections)}

Brains were sectioned at $40 \mu \mathrm{m}$ in the frontal plane through the hypothalamus. Immunohistochemistry for BrdU was performed on every fourth, free-floating section. Tissue was pretreated for BrdU immunostaining by DNA denaturation $\left(2 \mathrm{M} \mathrm{HCl}\right.$ at $37^{\circ} \mathrm{C}$ for $30 \mathrm{~min}$ ), followed by $10 \mathrm{~min}$ in borate buffer $(\mathrm{pH} \mathrm{8.5)}$. Sections were then incubated with rat anti-BrdU monoclonal antibody (1:400; Novus
Biologicals) for 72 hours. Sections were developed using the $\mathrm{ABC}$ and DAB methods (Vector Elite). Doublecortin staining was done using goat anti-doublecortin C-18 (DCX 1:1000; no. sc-8066, Santa Cruz Biotechnology). Homozygous male hypocretin-deficient mice were injected with morphine $(100 \mathrm{mg} / \mathrm{kg})$ subcutaneously. The control group received saline ( $n=3$ each group; table $\mathrm{S} 1$ ). The animals were sacrificed on day 14 , and hypocretin immunohistochemistry was performed.

\section{qPCR procedure}

The morphine escalating dose started from $100 \mathrm{mg} / \mathrm{kg}$ and was escalated by $20 \%$ every 72 hours, ending up at $180 \mathrm{mg} / \mathrm{kg}$ for 2 weeks. Brain samples from mice (eight saline-injected mice versus eight morphine-injected mice) were snap-frozen by dry ice and stored in $-80^{\circ} \mathrm{C}$. They were cut into $200-\mu \mathrm{m}$ sections in a cryostat at $-18^{\circ} \mathrm{C}$. The hypothalamus was bilaterally punched out by a prechilled $1.0-\mathrm{mm}$ punching needle (Miltex Inc.). Brain tissue samples were pooled with two animals in each tube and immediately put back on dry ice. The tissue was homogenized with $1000 \mu \mathrm{l}$ of QIAzol Lysis Reagent (QIAGEN Sciences) and $200 \mu \mathrm{l}$ of chloroform (Merck). RNA was isolated according to the RNeasy Lipid Tissue Mini Kit (catalog no. 74804, QIAGEN) manufacturer's protocol. RNA concentration and quality were measured by a Nanodrop TM ND-1000 spectrophotometer (Thermo Fisher Scientific). For each sample, $1000 \mathrm{ng}$ of total RNA was used for synthesis of complementary DNA (cDNA), as described by the manufacturer's protocol of the iScript cDNA Synthesis Kit (Bio-Rad Laboratories).

Primer sequences for preprohypocretin/orexin, preprodyn, and Narp GenBank accession code are indicated below. Primer sequences for glyceraldehyde-3-phosphate dehydrogenase, tubulin $\alpha-1 \mathrm{~A}$, ribosomal protein S28, actin- $\beta$, ubiquitin $C$, and tubulin $\beta-4 a$ (Tubb4a) were used as reference genes.

The qPCR procedures have been described previously (37). In short, qPCR was performed in a reaction volume of $20 \mu \mathrm{l}$ using the SYBR Green PCR Kit (Promega) and a mixture of sense and antisense primers $(2 \mathrm{pmol} / \mu \mathrm{l})$. Reactions were run in a GeneAmp 7300 thermocycler under the following conditions: $2 \mathrm{~min}$ at $50^{\circ} \mathrm{C}$ and $10 \mathrm{~min}$ at $95^{\circ} \mathrm{C}$, followed by 40 cycles of $15 \mathrm{~s}$ at $95^{\circ} \mathrm{C}$ and, finally, $1 \mathrm{~min}$ at $60^{\circ} \mathrm{C}$. Data were acquired and processed automatically by the Applied Biosystems Sequence Detection Software. Specificity of amplification was checked by melting curve analysis and electrophoresis of products on $1.5 \%$ agarose gel. Sterile water (nontemplate control) and omission of reverse transcriptase (non-RT control) during cDNA synthesis served as negative controls.

Amplification efficiency was determined by running qPCR reactions on a dilution series of pooled cDNA from all the subjects. Resulting cycle threshold values were plotted against the inverse log of each dilution, and the slope of this curve was then used to calculate the efficiency as follows: Efficiency $(E)=10^{-/ \text {slope }}$. The normalization factor was based on the geometric mean of the following two most stable reference genes (that is, actin- $\beta$ and Tubb4a) out of six candidate reference genes selected by geNorm analysis (38). To minimize handling variations, each gene was measured in triplicate. The relative absolute amount of target genes calculated (39) was divided by the normalization factor.

\section{Western blotting}

The mouse hypothalamus was sonicated in lysis buffer containing $50 \mathrm{mM}$ tris- $\mathrm{HCl}, 50 \mathrm{mM} \mathrm{MgCl}_{2}, 5 \mathrm{mM}$ EDTA, and a protease inhibitor tablet (catalog no. 12482000, Roche) and was centrifuged at 
$800 \mathrm{~g}(3000 \mathrm{rpm})$ for $30 \mathrm{~min}$ at $4^{\circ} \mathrm{C}$. The protein concentration of the supernatant was determined using the DC Protein Assay Kit (catalog no. 500-0112, Bio-Rad). Protein $(40 \mu \mathrm{g})$ was loaded on a $12 \%$ mini-protean TGX precast gel (catalog no. 456-1044, Bio-Rad) and separated at $50 \mathrm{~V}$. The proteins were then transferred to a polyvinylidene difluoride membrane (catalog no. 162-0176, Bio-Rad) at $50 \mathrm{~mA}$ for 2 hours. The membrane was washed in $20 \mathrm{mM}$ tris, $150 \mathrm{mM} \mathrm{NaCl}$, and $0.1 \%$ Tween 20 (TBST) and then blocked in TBST containing 5\% (w/v) nonfat dry milk (NFDM) for 1 hour. The membrane was incubated with rabbit anti-polyphenol oxidase (PPO) (sc-28935, Santa Cruz Biotechnology) and rabbit anti-MCH (sc-28931, Santa Cruz Biotechnology) at 1:1000 dilution in 2.5\% NFDM in TBST overnight at $4^{\circ} \mathrm{C}$. The next day, the membrane was washed in TBST before incubation with goat anti-rabbit horseradish peroxidase (HRP)-conjugated secondary antibody (catalog no. 31463, Thermo Fisher Scientific) at a dilution of 1:10,000 in 2.5\% NFDM in TBST for 1 hour at room temperature. After washing in TBST, the antibody complex was visualized with SuperSignal West Femto (catalog no. 34094, Thermo Fisher Scientific). Anti- $\beta$-actin (MAB1501R, Millipore) was used as an internal normalizer, at a dilution of $1: 10,000$, with goat anti-mouse HRP-conjugated secondary antibody (catalog no. A2304, Sigma) at a dilution of 1:10,000. The densities of $\mathrm{PPO}$, pro-MCH, and $\beta$-actin bands for each sample were measured using ImageJ software.

\section{Morphine administration to DTA mice}

To create a model of orexin/hypocretin deficiency with closer fidelity to human narcolepsy, DTA was expressed in orexin neurons under control of the Tet-off system (Fig. 6A) (11). Male orexin-tTA; TetO DTA mice were maintained from weaning to 10 weeks of age on DOX $(+)$ chow. To reduce the number of orexin neurons without elimination of the entire cell population, DOX $(+)$ chow was removed at 10 weeks of age and replaced with Labo MR stock food [DOX (-) condition] for 1.5 days, after which DOX $(+)$ chow was reintroduced ( 1.5 days + restoration of DOX; $n=8)$. The experimental group $(n=4)$ then received morphine $(100 \mathrm{mg} / \mathrm{kg})$ subcutaneously for 14 days, and the control group received $(n=4)$ saline. Two hours after last day injections, mice were deeply anesthetized with pentobarbital (100 mg/kg, i.p.) and perfused sequentially with $15 \mathrm{ml}$ of chilled saline and $15 \mathrm{ml}$ of chilled $10 \%$ formalin solution (Wako). Brains were isolated and immersed in formalin solution for 72 hours at $4^{\circ} \mathrm{C}$, followed by $30 \%$ sucrose. The sections were cut at $40 \mu \mathrm{m}$ and stained for hypocretin as described earlier.

\section{Cataplexy in DTA mice treated with morphine}

Female orexin-tTA; TetO DTA mice (40), aged 4 to 6 months fed DOX food from birth (as were their mothers before the birth of the pups), were placed on regular laboratory rodent food for 18 days and then back on DOX food (catalog no. TD.130840, Teklad) for 1 to 2 months (Fig. 6B). The mice were singly housed (lights on at 6:00 a.m. and off at 6:00 p.m.). The mice were recorded from 5:00 p.m. to 6:00 a.m. the next day, via a LOREX DV700 recording system with a 1080p HD MPX DVR. Chocolate ("Hershey's kisses," milk chocolate) was given at 6:00 p.m. to enhance cataplexy attacks (11). Baseline cataplexy was recorded between 6:00 p.m. and 6:00 a.m. the next morning, 1 day before morphine treatment commenced. At 10:00 a.m., the mice were injected subcutaneously with either saline or morphine $(50 \mathrm{mg} / \mathrm{kg})$. Morphine or saline was administered every day at 10:00 a.m. for 2 weeks. Overnight video recording was repeated weekly, after 1 and 2 weeks of morphine or saline injections and for 3 weeks after the termination of morphine/saline treatment. The number of cataplexy bouts was scored for the first 2 hours (from 6:00 p.m. to 8:00 p.m.) of the dark phase. Cataplexy was scored on the basis of the criteria of Chemelli et al. (9) and Scammell et al. (41): an abrupt episode of nuchal atonia with immobility lasting at least $10 \mathrm{~s}$, with at least $40 \mathrm{~s}$ of wakefulness preceding the episode. The number of cataplexy episodes was normalized with each subject's baseline score and was expressed as the percentage of saline control on week 1 .

\section{Effect of morphine on hypocretin cell activity in vivo}

Male Sprague-Dawley rats (Charles River Laboratories) weighing 250 to $300 \mathrm{~g}$ were used $(n=3)$. Hypocretin cells were recorded from the hypothalamus using microwire recording techniques as described previously (42). Under isoflurane anesthesia, microdrives containing 25- $\mu \mathrm{m}$ stainless steel microwires (California Fine Wire Co.) aimed at the lateral hypothalamic area were implanted, with the tip of the electrodes $0.5 \mathrm{~mm}$ above the target area. Stainless steel screw electrodes were placed over the sensorimotor cortex for EEG, and EMG activity was recorded from the dorsal neck muscles with Tefloncoated multistranded stainless steel wires (Cooner Wire). Animals were free to move around the recording chamber. Electrodes were moved in $80-\mu \mathrm{m}$ steps until a cell or cells with signal-to-noise ratio of at least 2:1 were isolated. The activity of each cell was then characterized throughout sleep/waking states. Waking-specific cells that fit the profile of hypocretin cells (10) were studied after intraperitoneal injections of morphine (10 to $15 \mathrm{mg} / \mathrm{kg}$ ) with continuous recording of neuronal activity for at least 3 hours.

\section{Statistical analysis}

The figure legends contain statistical details. The numbers of subjects in each human and animal study are indicated in Table 1 and table S1, respectively. Summary statistics are presented, with probability and df, in the figure legends. Unmatched two-tailed $t$ tests or ANOVAs were used as appropriate. The number of subjects was determined in each group, generating data according to the formula: $n=(z \text { score })^{2} \times \mathrm{SD} \times(1-\mathrm{SD}) /(\text { margin of error })^{2}$ with $\alpha$ set at 0.05 and power set at $80 \%$.

\section{SUPPLEMENTARY MATERIALS}

www.sciencetranslationalmedicine.org/cgi/content/full/10/447/eaao4953/DC1 Fig. S1. Western blots for Fig. 3 ( $D$ and $E$ ).

Table S1. Characteristics of animals used for morphine study.

\section{REFERENCES AND NOTES}

1. Centers for Disease Control and Prevention (CDC, 2017); www.cdc.gov/drugoverdose/ epidemic/.

2. C. Baimel, S. E. Bartlett, L.-C. Chiou, A. J. Lawrence, J. W. Muschamp, O. Patkar, L.-W. Tung, S. L. Borgland, Orexin/hypocretin role in reward: Implications for opioid and other addictions. Br. J. Pharmacol. 172, 334-348 (2015)

3. A. M. Blouin, I. Fried, C. L. Wilson, R. J. Staba, E. J. Behnke, H. A. Lam, N. T. Maidment, K. Æ. Karlsson, J. L. Lapierre, J. M. Siegel, Human hypocretin and melanin-concentrating hormone levels are linked to emotion and social interaction. Nat. Commun. 4, 1547 (2013).

4. R. McGregor, M.-F. Wu, G. Barber, L. Ramanathan, J. M. Siegel, Highly specific role of hypocretin (orexin) neurons: Differential activation as a function of diurnal phase, operant reinforcement vs. operant avoidance and light level. J. Neurosci. 31, 15455-15467 (2011).

5. T. C. Thannickal, R. Y. Moore, R. Nienhuis, L. Ramanathan, S. Gulyani, M. Aldrich, M. Cornford, J. M. Siegel, Reduced number of hypocretin neurons in human narcolepsy. Neuron 27, 469-474 (2000). 
6. R. Fronczek, S. Overeem, S. Y. Y. Lee, I. M. Hegeman, J. van Pelt, S. G. van Duinen, G. J. Lammers, D. F. Swaab, Hypocretin (orexin) loss in Parkinson's disease. Brain 130, 1577-1585 (2007).

7. T. C. Thannickal, Y.-Y. Lai, J. M. Siegel, Hypocretin (orexin) cell loss in Parkinson's disease. Brain 130, 1586-1595 (2007).

8. A. M. Blouin, T. C. Thannickal, P. F. Worley, J. M. Baraban, I. M. Reti, J. M. Siegel, Narp immunostaining of human hypocretin (orexin) neurons: Loss in narcolepsy. Neurology 65, 1189-1192 (2005).

9. R. M. Chemelli, J. T. Willie, C. M. Sinton, J. K. Elmquist, T. Scammell, C. Lee, J. A. Richardson, S. C. Williams, Y. Xiong, Y. Kisanuki, T. E. Fitch, M. Nakazato, R. E. Hammer, C. B. Saper, M. Yanagisawa, Narcolepsy in orexin knockout mice: Molecular genetics of sleep regulation. Cell 98, 437-451 (1999).

10. B. Y. Mileykovskiy, L. I. Kiyashchenko, J. M. Siegel, Behavioral correlates of activity in identified hypocretin/orexin neurons. Neuron 46, 787-798 (2005).

11. S. Tabuchi, T. Tsunematsu, S. W. Black, M. Tominaga, M. Maruyama, K. Takagi, Y. Minokoshi, T. Sakurai, T. S. Kilduff, A. Yamanaka, Conditional ablation of orexin/ hypocretin neurons: A new mouse model for the study of narcolepsy and orexin system function. J. Neurosci. 34, 6495-6509 (2014).

12. B. Falck, N.-Å. Hillarp, A. Torp, A new type of chromaffin cells, probably storing dopamine. Nature 183, 267-268 (1959).

13. A. Yamanaka, C. T. Beuckmann, J. T. Willie, J. Hara, N. Tsujino, M. Mieda, M. Tominaga, K.-i. Yagami, F. Sugiyama, K. Goto, M. Yanagisawa, T. Sakurai, Hypothalamic orexin neurons regulate arousal according to energy balance in mice. Neuron $\mathbf{3 8}, 701-713$ (2003).

14. C. Peyron, J. Faraco, W. Rogers, B. Ripley, S. Overeem, Y. Charnay, S. Nevsimalova, M. Aldrich, D. Reynolds, R. Albin, R. Li, M. Hungs, M. Pedrazzoli, M. Padigaru, M. Kucherlapati, J. Fan, R. Maki, G. J. Lammers, C. Bouras, R. Kucherlapati, S. Nishino, E. Mignot, A mutation in a case of early onset narcolepsy and a generalized absence of hypocretin peptides in human narcoleptic brains. Nat. Med. 6, 991-997 (2000).

15. T. C. Thannickal, R. Y. Moore, M. Aldrich, R. Albin, M. Cornford, J. M. Siegel, Human narcolepsy is linked to reduced number, size and synaptic bouton density in hypocretin-2 labeled neurons. Abstr. Soc. Neurosci. 26, 2061 (2000).

16. A. Crocker, R. A. España, M. Papadopoulou, C. B. Saper, J. Faraco, T. Sakurai, M. Honda, E. Mignot, T. E. Scammell, Concomitant loss of dynorphin, NARP, and orexin in narcolepsy. Neurology 65, 1184-1188 (2005).

17. J. John, T. C. Thannickal, R. McGregor, L. Ramanathan, H. Ohtsu, S. Nishino, N. Sakai, A. Yamanaka, C. Stone, M. Cornford, J. M. Siegel, Greatly increased numbers of histamine cells in human narcolepsy with cataplexy. Ann. Neurol. 74, 786-793 (2013).

18. P. O. Valko, Y. V. Gavrilov, M. Yamamoto, H. Reddy, J. Haybaeck, E. Mignot, C. R. Baumann, T. E. Scammell, Increase of histaminergic tuberomammillary neurons in narcolepsy. Ann. Neurol. 74, 794-804 (2013).

19. R. McGregor, L. Shan, M.-F. Wu, J. M. Siegel, Diurnal fluctuation in the number of hypocretin/orexin and histamine producing: Implication for understanding and treating neuronal loss. PLOS ONE 12, e0178573 (2017).

20. M. S. Mazei-Robison, J. W. Koo, A. K. Friedman, C. S. Lansink, A. J. Robison, M. Vinish, V. Krishnan, S. Kim, M. A. Siuta, M. A. Galli, K. D. Niswender, R. Appasani, M. C. Horvath, R. L. Neve, P. F. Worley, S. H. Snyder, Y. L. Hurd, J. F. Cheer, M.-H. Han, S. J. Russo, E. J. Nestler, Role for mTOR signaling and neuronal activity in morphine-induced adaptations in ventral tegmental area dopamine neurons. Neuron 72, 977-990 (2011).

21. Y. Li, A. N. van den Pol, $\mu$-Opioid receptor-mediated depression of the hypothalamic hypocretin/orexin arousal system. J. Neurosci. 28, 2814-2819 (2008).

22. Y. Dauvilliers, R. Lopez, M. Ohayon, S. Bayard, Hypersomnia and depressive symptoms: Methodological and clinical aspects. BMC Med. 11, 78 (2013)

23. G. B. Stefano, R. M. Kream, Endogenous morphine synthetic pathway preceded and gave rise to catecholamine synthesis in evolution (Review). Int. J. Mol. Med. 20, 837-841 (2007).

24. R. Sharf, M. Sarhan, R. J. DiLeone, Orexin mediates the expression of precipitated morphine withdrawal and concurrent activation of the nucleus accumbens shell. Biol. Psychiatry 64, 175-183 (2008).

25. G. C. Harris, M. Wimmer, G. Aston-Jones, A role for lateral hypothalamic orexin neurons in reward seeking. Nature 437, 556-559 (2005).

26. W. Sun, Dopamine neurons in the ventral tegmental area: Drug-induced synaptic plasticity and its role in relapse to drug-seeking behavior. Curr. Drug Abuse Rev. 4, 270-285 (2011).

27. F. Torrealba, M. Yanagisawa, C. B. Saper, Colocalization of orexin a and glutamate immunoreactivity in axon terminals in the tuberomammillary nucleus in rats. Neuroscience 119, 1033-1044 (2003).

28. S. Bingham, P. T. Davey, A. J. Babbs, E. A. Irving, M. J. Sammons, M. Wyles, P. Jeffrey, L. Cutler, I. Riba, A. Johns, R. A. Porter, N. Upton, A. J. Hunter, A. A. Parsons, Orexin-A, an hypothalamic peptide with analgesic properties. Pain 92, 81-90 (2001).
29. G. Aston-Jones, R. J. Smith, G. C. Sartor, D. E. Moorman, L. Massi, P. Tahsili-Fahadan, K. A. Richardson, Lateral hypothalamic orexin/hypocretin neurons: A role in rewardseeking and addiction. Brain Res. 1314, 74-90 (2010).

30. D. Georgescu, V. Zachariou, M. Barrot, M. Mieda, J. T. Willie, A. J. Eisch, M. Yanagisawa E. J. Nestler, R. J. DiLeone, Involvement of the lateral hypothalamic peptide orexin in morphine dependence and withdrawal. J. Neurosci. 23, 3106-3111 (2003).

31. J. M. Harper, Gelineau's narcolepsy relieved by opiates. Lancet 317, 92 (1981).

32. S. R. Benbadis, Effective treatment of narcolepsy with codeine in a patient receiving hemodialysis. Pharmacotherapy 16, 463-465 (1996).

33. J. M. Fry, M. R. Pressman, M. A. DiPhillipo, M. Forst-Paulus, Treatment of narcolepsy with codeine. Sleep 9, 269-274 (1986).

34. J. K. Mai, J. Assheuer, G. Paxinos, Atlas of the Human Brain (Elsevier Academic Press, 2004).

35. R. Fronczek, S. Overeem, S. Y. Y. Lee, I. M. Hegeman, J. van Pelt, S. G. van Duinen, G. J. Lammers, D. F. Swaab, Hypocretin (orexin) loss and sleep disturbances in Parkinson's disease. Brain 131, e88 (2008).

36. R. W. H. Verwer, J. E. Raber-Durlacher, Efficient and unbiased estimation of volume and area of tissue components and cell number in gingival biopsies. J. Periodontal Res. 28, 313-323 (1993).

37. L. Shan, K. Bossers, S. Luchetti, R. Balesar, N. Lethbridge, P. L. Chazot, A. M. Bao, D. F. Swaab, Alterations in the histaminergic system in the substantia nigra and striatum of Parkinson's patients: A postmortem study. Neurobiol. Aging 33, 1488.e1-1488.e13 (2012).

38. J. Vandesompele, K. De Preter, F. Pattyn, B. Poppe, N. Van Roy, A. De Paepe, F. Speleman, Accurate normalization of real-time quantitative RT-PCR data by geometric averaging of multiple internal control genes. Genome Biol. 3, RESEARCH0034 (2002).

39. W. Kamphuis, A. Schneemann, L. M. van Beek, A. B. Smit, P. F. J. Hoyng, E. Koya, Prostanoid receptor gene expression profile in human trabecular meshwork: A quantitative real-time PCR approach. Invest. Ophthalmol. Vis. Sci. 42, 3209-3215 (2001).

40. S. Inutsuka, S. Tabuchi, T. Tsunematsu, S. W. Black, T. S. Kilduff, A. Tominaga, A. Yamanaka, New model mice for narcolepsy using timing controlled gene expression in transgenic mice which induces specific ablation of orexin/hypocretin neurons. Soc. Neurosci. 799, 19 (2012).

41. T. E. Scammell, J. T. Willie, C. Guilleminault, J. M. Siegel, A consensus definition of cataplexy in mouse models of narcolepsy. Sleep 32, 111-116 (2009).

42. M.-F. Wu, S. A. Gulyani, E. Yau, E. Mignot, B. Phan, J. M. Siegel, Locus coeruleus neurons: Cessation of activity during cataplexy. Neuroscience 91, 1389-1399 (1999).

Funding: This study was supported by NIDA grant DA034748, the Medical Research Service of the Department of Veterans Affairs grant BX001753 (J.M.S.), NARSAD Young Investigator Grant from the Brain and Behavior Research Foundation (L.S.), and grant R35NS097966 (P.F.W.). Author contributions: T.C.T. collected and analyzed the morphine administration data from the wild-type mice. T.C.T. and J.J. analyzed the data from human opiate addicts. J.J. collected BrdU and doublecortin labeling data. L.S. measured changes in mRNA of preprohypocretin, Narp, and preprodynorphin after morphine administration and identified and analyzed the data on hypocretin in postmortem brain tissue from human narcoleptic patients and control individuals together with D.F.S. M.-F.W. did the neuronal recording in freely moving rats in response to morphine and analyzed the effects of opiates on narcolepsy in hypocretindepleted mice. L.R. studied the effects of morphine on preprohypocretin and preproMCH using Western blotting. R.M. assisted in neuronal recording from hypocretin cells. K.-T.C. conducted quantitative microscopic analysis of control and opiate-treated wild-type mice and of DTA hypocretin-depleted and morphine-treated DTA mice. M.C. conducted neuropathological screening on all of the human postmortem brains. A.Y. created the DTA mouse line, and A.I. performed the hypocretin depletion experiments and the reversal of the reduced number of neurons detected after morphine administration. R.F. and G.J.L. diagnosed and treated the human narcoleptic patients. R.F. counted the hypocretin neurons in three control brains from the Netherlands Brain Bank. P.F.W. assisted with the Narp analysis. J.M.S. advised on all studies and wrote the initial and final drafts of the manuscript. All authors assisted in writing the paper. Competing interests: G.J.L. consults for Jazz Pharmaceuticals and Bioprojet. All other authors declare that they have no competing interests. Data and materials availability: All data are in the paper and the Supplementary Materials.

Submitted 26 July 2017

Resubmitted 18 September 2017

Accepted 26 January 2018

Published 27 June 2018

$10.1126 /$ scitranslmed.aao4953

Citation: T. C. Thannickal, J. John, L. Shan, D. F. Swaab, M.-F. Wu, L. Ramanathan, R. McGregor, K.-T. Chew, M. Cornford, A. Yamanaka, A. Inutsuka, R. Fronczek, G. J. Lammers, P. F. Worley, J. M. Siegel, Opiates increase the number of hypocretin-producing cells in human and mouse brain and reverse cataplexy in a mouse model of narcolepsy. Sci. Transl. Med. 10, eaao4953 (2018). 


\section{Science Translational Medicine}

\section{Opiates increase the number of hypocretin-producing cells in human and mouse brain and reverse cataplexy in a mouse model of narcolepsy}

Thomas C. Thannickal, Joshi John, Ling Shan, Dick F. Swaab, Ming-Fung Wu, Lalini Ramanathan, Ronald McGregor, Keng-Tee Chew, Marcia Cornford, Akihiro Yamanaka, Ayumu Inutsuka, Rolf Fronczek, Gert Jan Lammers, Paul F. Worley and Jerome M. Siegel

Sci Transl Med 10, eaao4953.

DOI: $10.1126 /$ scitranslmed.aao4953

\section{Opiate addiction and narcolepsy: Opposite sides of the same coin?}

The neurological mechanisms that maintain opiate addiction and prevent long-term withdrawal are not well understood. In a new study, Thannickal et al. found that human heroin addicts have, on average, 54\% more hypocretin-producing neurons than do neurologically normal control individuals. They show that a similar increase in hypocretin-producing neurons could be induced in mice through long-term morphine administration. This long-lasting increase in hypocretin neurons may be responsible for maintaining addiction. Narcolepsy is caused by a loss of hypocretin-producing neurons. Morphine administration restored the population of hypocretin neurons in $\mathrm{h}$ ypocretin cell-depleted mice back to normal numbers and decreased cataplexy in narcoleptic animals. Induction of specific long-term changes in neuropeptide production, outlasting the half-life of the administered drugs, may be useful in treating diseases characterized by loss of neurons producing these neuropeptides.

ARTICLE TOOLS

SUPPLEMENTARY MATERIALS

RELATED

REFERENCES

PERMISSIONS http://stm.sciencemag.org/content/10/447/eaao4953

http://stm.sciencemag.org/content/suppl/2018/06/25/10.447.eaao4953.DC1

http://stm.sciencemag.org/content/scitransmed/10/434/eaan2595.full http://stm.sciencemag.org/content/scitransmed/8/351/351 ra106.full http://stm.sciencemag.org/content/scitransmed/10/442/eaar3752.full

This article cites 40 articles, 5 of which you can access for free http://stm.sciencemag.org/content/10/447/eaao4953\#BIBL

http://www.sciencemag.org/help/reprints-and-permissions

Science Translational Medicine (ISSN 1946-6242) is published by the American Association for the Advancement of Science, 1200 New York Avenue NW, Washington, DC 20005. 2017 () The Authors, some rights reserved; exclusive licensee American Association for the Advancement of Science. No claim to original U.S. Government Works. The title Science Translational Medicine is a registered trademark of AAAS. 